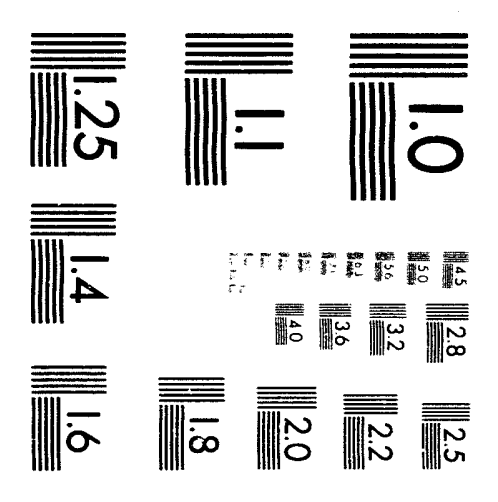



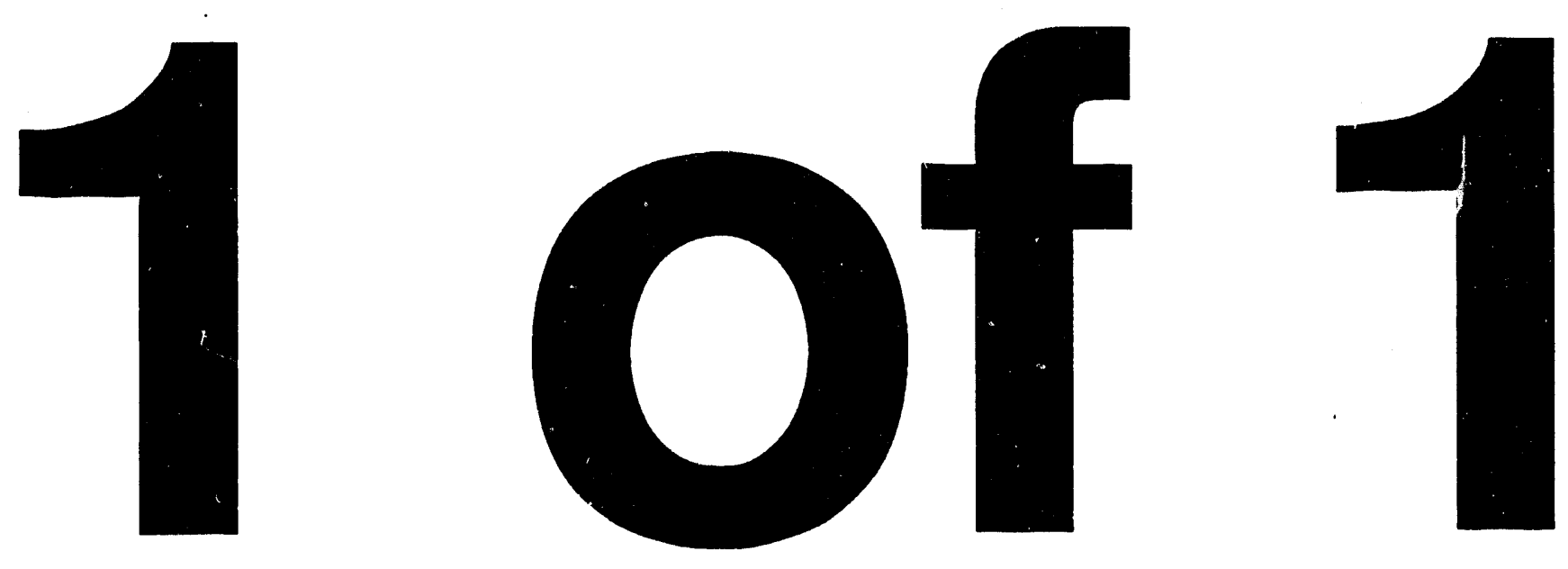


\section{$D G E / C E / 27504 \ldots 74$}

June 1993

\section{NEGOTIATING A DEMAND SIDE BID: CITY OF SAN JOSE CASE STUDY}

Energy Task Force of the Urban Consortium

Energy, Environment, and Economic Development Unit

CITY OF SAN JOSE ENVIRONMENTAL SERVICES

DEPARTMENT

Rita Norton

Unit Manager,

Conservation Services

Division

Lidia Liu

Project Director

Larry Owens

Project Manager
Leslie R. White

City Manager

CITY COUNCIL

Susan Hammer, Mayor

Blanca Alvarado, Vice Mayor

James T. Beall, Jr.

Kathy Cole

Margie Fernandes

Frank Fiscalini

Joe Head

Trixie Johnson

David Pandori

Charlotte Powers

George Shirakawa

\section{MASTER}




\section{Urban Consortium Energy Task Force Publications}

With staff, management, and business services pro vided by PTI, the Urban Consortium (UC) addresses the critical needs of large local governments through 3 task forces: Energy, Environment, and Telecommunications and Information. The Urban Consortium Energy Task (UCETF) was set up with the main objective to improve urban energy management and decision-making through applied research and technology transfer.

The UCETF focuses on developing and sharing new approaches and innovative solutions to energy management problems with local governments. Projects are organized in thematic units and co-managed by a member of the Task Force.

A description of the Units and projects included in the 1992 program are as follows:

\section{ENERGY, ENVIRONMENT, ECONOMIC AND SOCIAL DEVELOPMENT}

"Sustainability" is a planning goal to provide an integrative systems approach to meeting all our needs for today and tomorrow. Evaluating the needs of citizens and developing effective and efficient ways to meet those needs is a primary responsibility of local governments. Cities and counties are currently beset by a wide range of problems that in fact are symptoms of some common and pervasive ills. Our problems with energy, environment, economic and social development are related in a complex and interdependent way. These problems, therefore, cannot be effectively solved through a piecemeal approach without recognizing and addressing the interdependent relationships between these areas. The 1992 Energy, Environment, Economic and Social Development consist of:

Dade County, FL - A Long Term Urban Carbon Dioxide Emission Reduction Program

Pima County, AZ - Sustainable Community Implementation Partnership
Portland, OR - Sustainable Business Development Program

San Jose, CA - Negotiating a Demand Side Bid: The City of San Jose Case Study

San Jose, CA - "Green Aisle" Research Program

Santa Clara, CA - Fuel Cell Demonstration Partnership Program

Austin, TX - Sustainable Building Sourcebook

Chicago, IL - Downtown District Cooling: A 21 st Century Approach

Chicago, IL - Role of Municipal Governments in the Design and Implementation of Energy Efficiency Codes and Standards Designed to Capture Lost Efficiency Opportunities

Seattle, WA - Coordination of Energy and Air Quality (CEAM)

St. Louis, MO - Earthways Home Project: An Educational Center for Sustainable Urban Development

Tucson, AZ - Minority Marketing for Resource Conservation

Washington, DC - Energy Auditor Training Course for High School Students

\section{ENERGY EFFICIENT FACILTIES}

Activities involving energy efficient facilities are part of a national effort to achieve maximum costeffective energy productivity in the building sector. New technologies and management/administration practices to advance energy efficiency in facilities require major partmership efforts and transfer programs. Multifamily housing that has a large concentration of lowincome families presents a unique challenge to lowering energy costs and maintaining energy efficient facilities. Both existing building stock and near-term new construction need to be made much more energy efficient if we are to meet local, state, and national objectives related to energy security, energy supply, and energy affordability. Space heating and cooling, lighting, water heating, refrigeration, cooking, ventilation, building envelope, energy efficientcodes implementation, operation and maintenance (O\&M), education, etc. are areas where opportunities exist to improve energy efficiency. The 1992 Energy Efficient Facilities Unit consists of: 
Boston, MA - Energy Efficiency Outreach Partnership

Columbus, $\mathrm{OH}$ - Integrating Operations and Maintenance (O\&M) for Energy Efficiency with O\&M for Improving Indoor Air Quality

Hennepin County, MN - Integrated Rehab and Weatherization Program for Low income Suburban Homeowners

Memphis, TN - Upgrade Energy Building Standards and Develop Rating System for Existing Low-Income Housing

New Orleans, LA - Utilization of Energy Efficiency to Support Homeownership Affordability

Detroit, $\mathbf{M I}$ - Energy Optimization of Water Distribution System

Montgomery County, MD - CFC Maintenance and Conversions in Chillers: The Commercial Building Response to the 1990 Clean Air Act

New York City, NY - Development of an Energy Services Corporation

Phoenix, AZ - Solar Cooling Demonstration Project

San Francisco - Energy Management Action Plan (EMAP)

\section{TRANSPORTATION}

It is frequently said that the goal of transportation strategies should be moving people, not vehicles. But in the day and age of satellite networks, cellular phones, and personal computers, we can redefine transportation as access to goods, services, and information to meet the needs of local governments and their citizerıs. Alternative transportation fuels are still a najor piece in a very large and complex puzzle facing local governments that includes wide-reaching concerns about transportation. There are many factors related to transportation that affect local governments: increasing congestion, crumbling infrastructure of roads and bridges, unchecked urban/suburban sprawl, and the increased "paving over" of our communities that leads to urban heat islands. Federal, state, and urban governments each share in the responsibility and must play a role in providing a sustainable and multi-faceted transportation system that is based on comprehensive and integrated planning at all levels. The 1792 Transportation unit consists of:

Houston, $\mathbf{T X}$ - Public/Private Partnership to Identify Barriers \& Provide Solutions to Implement Large Scale Fleet Natural Gas Vehicle Utilization in Ozone Non-attainment Areas

New York City, NY - Energy and Economic Implications of Transportation Demand Management Strategies

Pittsburgh, PA - Natural Gas infrastructure Development

Seattle, WA - Telecommuting for City Employees

Albuquerque, NM - A Fully Integrated Multi-Fuels Service Stations

Denver, CO - Tecinnical Comparison Between Hythane $\left(\mathrm{H}_{2}, \mathrm{CN}(\mathrm{S})\right.$ and $\mathrm{CNG}$ Fueled Vehicles

Las Vegas, NV --- Reduction of Diesel Exhaust Emissions in Urban Mass Transit Vehicles with Alcohol Injection Systems

San Diego City, CA A - California Clean Air Act - A Compliance Strategy for the City of San Diego's Non-Emergen:y Fleet

Reports from each of these research projects, including this report, are specifically designed to aid the transfer of proven experience to other local governments. Readers interested in obtaining additional reports or further information about the Urban Consorfium Energy Task Force should contact:

\section{Energy R,D\&C Program Public Technology, Inc. 1301 Pennsylvania Avenue, NW Suite 800 Washington, DC 20004}

\section{Tel: $\quad 1-800 / 852-4934$ or 202/626-2400}

Fax: $202 / 626-2498$ 


\section{PROJECT PURPOSE}

Within the context of a Sustainable City Strategy, the purpose of this project was to:

- Investigate the potential benefits to local governments from participating in this auction-style, energy-conservation incentive program - known as demand side bidding (DSB);

and then,

- document a case study detailing the organization, preparation, and submittal of a proposal to Pacific Gas and Electric's DSB program.

This project sought to establish an important precedent for other cities. The energy-conservation bidding process is a mystery to many, and examples of demand side management (DSM) contracts between a city and a utility were previously non-existent. This report offers other cities helpful information and insight by detailing a case study of the City of San Jose's participation in Pacific Gas and Electric's pilot DSB-PowerSaving Partners. 


\section{ACKNOWLEDGEMENTS}

Over the last three years, City of San Jose staff have contributed to the development of programs which would strengthen municipal and utility partnerships aimed at implementing programs which conserve energy. A major milestone in furthering the attainment of this goal is documented in this report. The collaborative efforts to research, prepare, negotiate, and secure the demand side bid with PG\&E involved the active participation of the following City of San Jose staff members: Gary Liss, Cesar Dablo, Lidia Liu, Larry Owens, Nayeem Sheikh, Mary Tucker, John Bidwell, Greg Larson, Charles Daniels, Rob Kolar, Eric Wilkinson, Stacey Klopfer, Kathy Pool, Mollie Dent, Lou Garcia, Debra. Figone, Jose Garcia, Frank Lettieri, and Ramona Sierras-Hodge. I also wish to recognize the assistance of Synergic Resources Corporation and SK Writers, Inc.

We wish to recognize the leadership of the program planners at PG\&E who have been responsible for the development and negotiation of PG\&E's PowerSaving Partners Program, in particular, Cathy Berman, Suzanne Cutts, and Rob Chapman. In addition, I wish to recognize the contribution and leadership provided by the National Programs Division at the Department of Energy, in particular Frank Stewart and Linda de la Croix; by the Chairman of the Urban Consortium, Mike Lindberg from the City of Portland, Oregon; by the staff at the Business Office of the Energy Task Force, specifically, Charles Williams and Linda Davis of the City of Chicago; and the on-going staff support from Public Technology, Inc., namely, Jack Werner, Linda Keenan, and Ama Frimpong.

The research and studies described in this report were made possible by grants from the United States Department of Energy through the Energy Task Force of the Urban Consortium for Technology Initiatives.

Rita Norton, Program Manager

Conservation Services Division

Environmental Services Department

June 1993 


\section{CONTENTS}

PAGE NO.

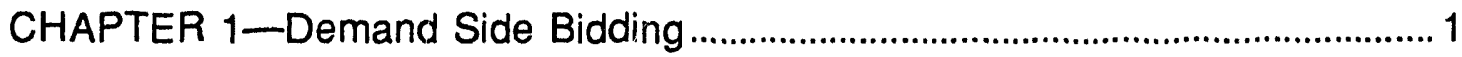

Demand Side Bidding as a Demand Side Management Program............ 1

PG\&E's Demand Side Bid-PowerSaving Partners................................... 2

PG\&E's RFP Objectives .......................................................................... 2

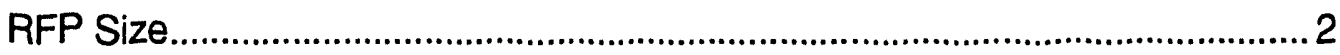

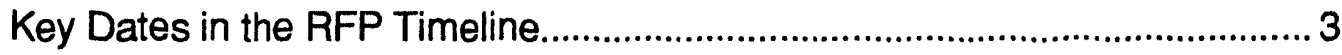

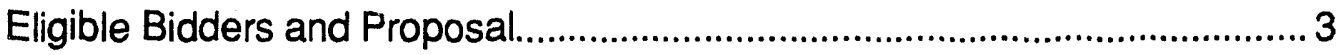

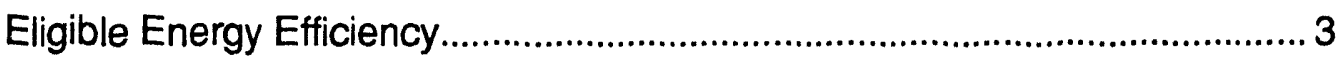

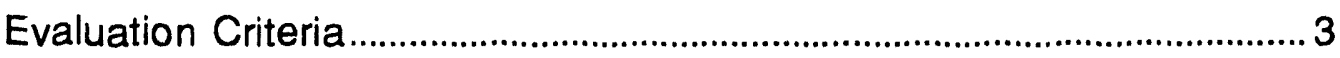

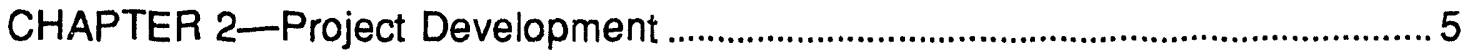

San Jose and the Office of Environmental Management............................. 5

Project Development and Application ........................................................ 5

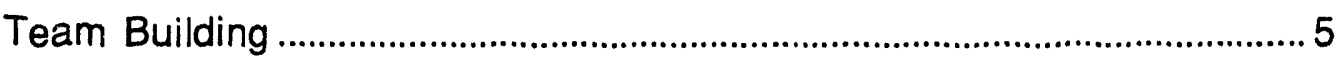

Soliciting of Bidding Co-Participants ......................................................... 5

Interpretation of PG\&E's Bidding Parameters ............................................. 6

Scenario-Driven Cost-Benefit Analysis ......................................................... 6

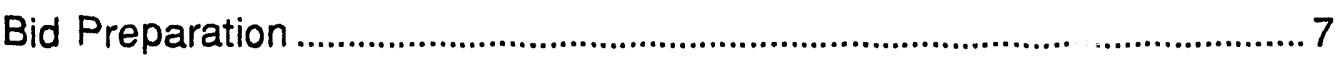

Defining the Case Study .......................................................................

CHAPTER 3 - Setting the Context for Participation .................................................. 9

Setting Minimum Benefit Thresholds for Continued Participation.............. 9

CHAPTER 4-Investigation of Participation Scenarios........................................11

Identifying Potential Participation Scenarios.............................................11

Determining a Participation Scenario...................................................... 13

Outcome of Scenario Choices ................................................................. 14

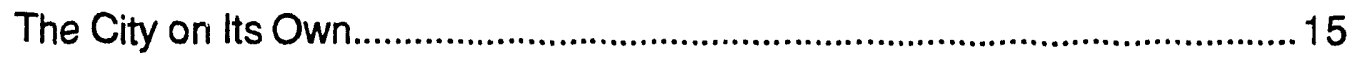

CHAPTER 5-Interpretation of Bid Evaluation Criteria .......................................17

Economic Attribute (45\%)......................................................................... 17

Total Net Avoided Cost (TNAC) …………............................................ 18

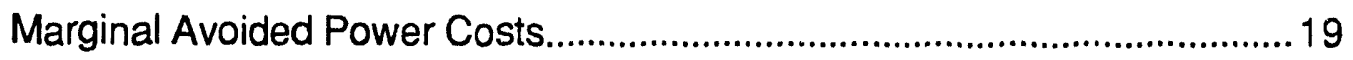

Customer Contribution Plus Bid Payment for Total Cost...........................20 


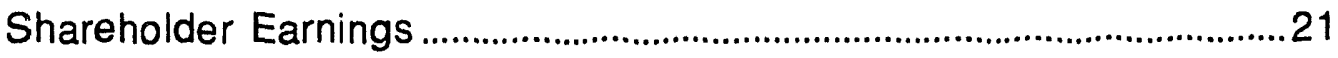

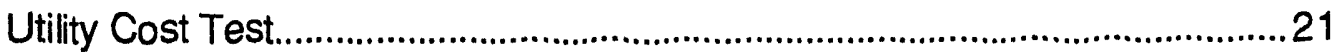

Measurement and Verification (M\&V) Attribute (15\%)..............................21

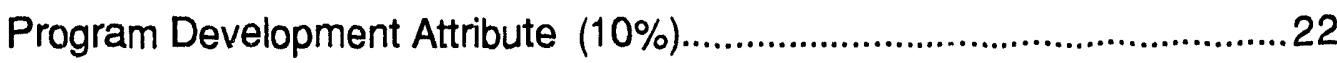

Marketing Plan Attribute (10\%) ................................................................23

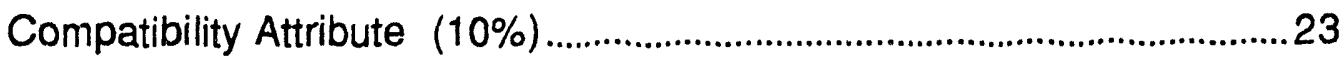

Comprehensiveness Attribute $(7 \%)$........................................................23

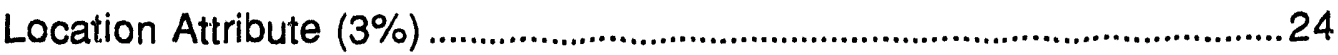

Interdependent Evaluation Criteria .........................................................24

CHAPTER 6-Analysis of the City of San Jose's Proposal.................................27

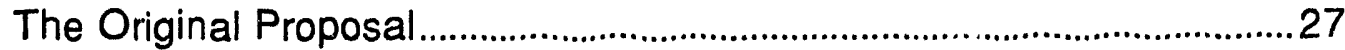

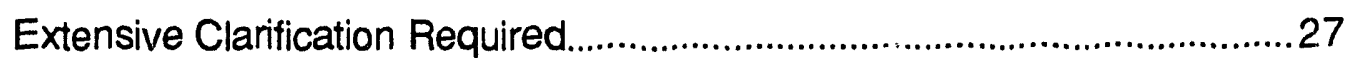

Substitutions to the Original Proposal ........................................................27

Analysis of the City's Proposal.................................................................28

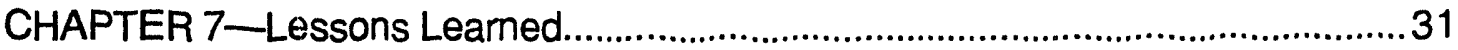

Working Within the City Structure ................................................................31

Re-Assessing the RFP Priorities ...............................................................

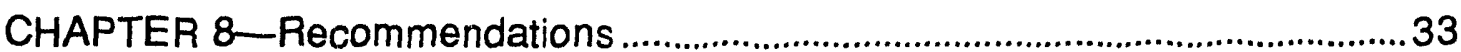

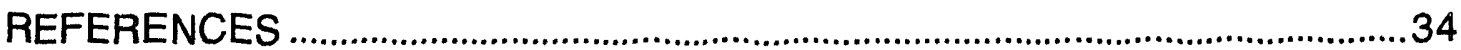

APPENDIX A

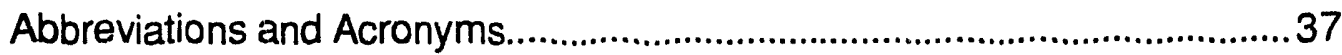

APPENDIX B

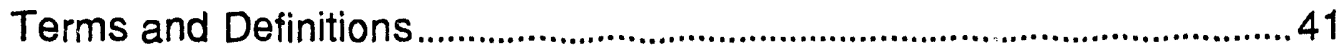

APPENDIX C

PowerSaving Partners: List of Measures .....................................................4

APPENDIX D

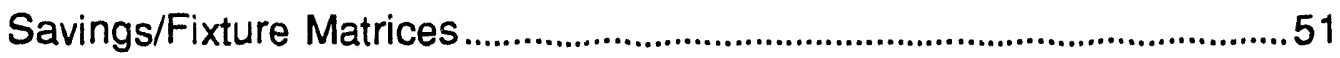




\section{LIST OF TABLES}

PAGENO.

Table 1. Key dates in the RFP timeline...................................................................... 3

Table 2. Potential participation scenario advantages and disadvantages................. 12

Table 3. Projected power savings of proposed lighting retrofits................................. 18

Table 4. Marginal avoided power costs ....................................................................... 19

Table 5. Customer contribution plus bid payment for total project cost......................20

Table 6. Summary of differences between City's original and final proposals...........28

Table 7. Summary of self-evaluation of the City's original and final proposals..........29 


\title{
Negotiating a Demand Side Bid: City of SAN Jose Case Study
}

\begin{abstract}
A major issue San Jose and other cities face in implementing energy conservation programs is lack of funding. A new source of funds for community energy management may be available from utility sponsored, auction-style, demand side management (DSM) programs generally known as demand side bidding (DSB). With the support of an Urban Consortium Energy Task Force grant, the City of San Jose studied potential scenarios for DSB participation, determined overall benefits of participation, prepared and submitted a bid proposal, and negotiated a contract. After more than a year of following and analyzing the development of PG\&E's pilot DSB program, called PowerSaving Partners, the City of San Jose concluded that there was a clear and substantial benefit available to local government participants with qualifying projects and proposals. On October 15, 1992, PG\&E released its Request for DSB Proposals and the City of San Jose responded, as a customer-bidder, by submitting a proposal to produce a $530 \mathrm{~kW}$ energy conservation package. The package consisted mostly of lighting retrofits, but also included a pottery kiln replacement and three HVAC measures. Forty-two proposals were submitted to $P G \& E$, of which only 13 were selected. After changes to the proposal were submitted, the City of San Jose's bid was selected as one of the winning submissions. The City proposed receiving payments of between $85 \%$ and $115 \%$ of the utility's avoided costs. Suggested annual incentive payments at $\$ 52,366$ per year to the City of San Jose were expected to continue through 2003 , totaling about $\$ 470,000$. The estimated utility savings, at $\$ 96,000$ per year, would produce $\$ 864,000$ in accumulated savings in nine years. The initial investment of $\$ 345,000$ is estimated to produce a net financial benefit of $\$ 989,000$ over nine years to the City of San Jose while helping PG\&E to avoid expensive investments in fuel-intensive power plants. This report enphasizes the transferability of the gathered information to other local municipal governments. The report particularly provides: general background information on demand side bidding; advantages and disadvantages of participation; alternative and "ideal" scenarios for bidding; review of potential pitfalls and lessons learned; and a general framework of information based on this particular request for DSB proposals and the City of San Jose's response experience.
\end{abstract}




\section{CHAPTER 1-Demand Side Bidding}

\section{Demand Side Bidding as a Demand Side Management Program}

Demand side management (DSM) programs offer temporary relief to utilities by postponing the need to build costly generating plants. Increasingly, however, regulators are pressuring utilities to develop programs that provide rate payers with a larger share of the benefits associated with energy-efficiency investments.

Demand side bidding (DSB) programs provide a unique way for cities to secure this larger share and enhance their penetration of energy conservation measures. DSB is a development in DSM which is based, in part, on experiences in supply-side bidding. In supply-side bidding, a utility would release a Request for Proposals (RFP) soliciting bids from potential energy producers to provide that utility with a certain amount of generated power. A winning supply-side bid would propose to provide this power (megawatts) at a competitive price to the purchasing utility. Similarly, a DSB RFP would solicit proposals from potential energy conservers. A winning demand side bid would propose to provide conserved power (negawatts) for a competitive price. (Vine 1990)

Producing a winning bid results in financial incentives from utilities far higher than those available through traditional DSM programs. With higher incentives, previously marginal projects become financially attractive. Utilities win by reducing their energy demand and avoiding the construction of higher-cost power generation facilities. Cities win by gaining a new revenue stream and by installing energy-saving measures they might not ordinarily pursue. A successful DSB program results in a reduction in utility bills for participants and a reduction in the environmental impact of producing energy.

Development of this type of program, as well as other DSM programs, represents a transitional period in power development. For local governments, a "window of opportunity" opens to reap the financial benefits of incentive programs. DSB programs offer cities the potential to receive the best incentives to date.

Potential for reward through a DSB program is somewhat limited by the process required to receive the reward. Demand side bidding is far more complex than conventional DSM programs. Depending on the objectives of a particular program, a multitude of variables, requirements and risks are attached to the development of a proposal, execution of a contract, implementation of the measures and verification of the savings. DSB programs can vary in several aspects:

- the minimum size of an individual proposal;

- the maximum size of the entire program;

- eligibility requirements for the bidders, host facilities and the type of measures proposed;

- category, weight and definition of the evaluation criteria;

and

- the duration and format of the final contract. 
DSB programs differ greatly from conventional conservation incentive programs in that:

- DSBs target both utility customers and third party providers. Third party providers are entities which use utility-customer's facilities as "hosts" for their energy conservation measures (e.g., energy service companies or ESCOs).

- DSM bidders often assume some of the long-term performance risks and initial marketing costs. In conventional programs, these risks and cost are borne by the utility and its ratepayers.

and

- Financial incentives offered by the utility to promote DSM are not always front-loaded and are often tied to the actual performance of the measure over several years. Onetime, up-front rebates, typical to conventional DSM programs, are unaffected by actual measured performance. (Goldman and Wolcott 1990)

In California, the California Public Utilities Commission (CPUC) has required utilities to be structured so that benefits from energy efficiency investments are shared between rate payers and utility shareholders. This realignment of incentives resulted in the adoption of the first DSB program in the state. PG\&E- the nation's largest investor-owned utility and supplier of electricity to the City of San Jose-was the first investor-owned utility in California to announce its version of a DSB. They requested authorization from the CPUC to spend \$5 million in 1992 for developing and implementing a pilot program called PowerSaving Partners.

\section{PG\&E's Demand Side Bid-PowerSaving Partners}

PG\&E, in conjunction with the CPUC, combined previous experiences from other DSBs and created a "state-of-the-art" package. As such, PG\&E's DSB framework represented many of the current trends in DSB programs and provided a good basis for the transferability of program descriptions and analysis. This report draws its context primarily from the structure and detail of the PG\&E PowerSaving Partners RFP.

\section{PG\&E's RFP Objectives}

1. Work in positive partnership with winning bidders (third party providers and/or customers) to achieve energy efficiency opportunities.

2. Increase and expedite energy efficiency market penetration.

3. Secure energy savings that persist over time.

4. Acquire energy efficient resources at the lowest practicable cost tempered by market and resource types.

\section{RFP Size}

The PowerSaving Partners RFP sought about 20 MW of capacity savings. This amount was reduced from $50 \mathrm{MW}$ early in the RFP development and represented a small portion of PG\&E's total DSM goal of 2,500 MW. 


\section{Key Dates in the RFP Timeline}

Prospective bidders were given three months after the release of the RFP to submit their bids. After the January bidding due date, a three-nonth period was set to allow PG\&E to review and clarify each bid before announcing short-list status. Four months were allotted for contract negotiations. Before implementing any projects, this ten-month process must be successfully completed.

Table 1. Key dates in the RFP timeline.

\begin{tabular}{|ll|}
\hline Date(s) & Milestone \\
\hline October 15, 1992 & RFP issued \\
November 13,1992 & Pre-bid conference \\
December 15, 1992 & Notice of intent to bid due \\
January 15, 1993 & Proposals due \\
January 15-April 15, 1993 & Bid scoring \\
April 15, 1993 & Announcement of short list \\
April-August 1993 & Negotiations and contract signing \\
August 1993 & Negotiation period ends \\
\hline
\end{tabular}

\section{Eligible Bldders and Proposal}

Eligible bidders included any PG\&E customers and third parties capable of providing a proposal of retrofit/replacement measures in facilities located in any of PG\&E's service territories. Each proposal was required to achieve a minimum of $100 \mathrm{~kW}$ in capacity savings and/or 100,000 annual kWh in energy savings. The maximum savings which could be proposed was $20 \mathrm{MW}$.

\section{Eligible Energy Efficiency}

Electric- and gas-efficient proposals which use commercially available and proven technologies-including load-management proposals that reduce electricity or gas consumption-were eligible for this RFP. Gas-saving proposals were required to include an electric efficiency component. Proposals achieving energy savings through behavioral changes were also eligible.

Proposals not eligible included generating technologies that bypass power purchasing (such as cogeneration, solar photovoltaics, and wind turbines) and proposals that reduced the use of power through cessation of use or termination of a process.

\section{Evaluation Criteria}

Economic attributes of a DSB are often primary to the selection process. Evaluation criteria other than price can be extensive and vary widely from program to program depending on the goals of a particular program. For PG\&E's PowerSaving Partners, the evaluation criteria and their weights in the selection process were: 


$\begin{array}{lr}\text { Economic Attribute } & 45 \% \\ \text { Measurement and Verification Plan Attribute } & 15 \% \\ \text { Program Development Attribute } & 10 \% \\ \text { Marketing Plan Attribute } & 10 \% \\ \text { Compatibility with PG\&E Energy Efficiency Programs Attribute } & 10 \% \\ \text { Comprehensive Package Attribute } & 7 \% \\ \text { Location Attribute } & 3 \%\end{array}$

Although evaluation of the proposal attributes was broken down and scored in discrete components, each of the attributes was not independent of the cthers. Interdependency could cause a certain provision to be beneficial to one or more categories, detrimental to one or more categories, or cause a combination of conflicting effects. 


\section{CHAPTER 2-Project Development}

\section{San Jose and the Office of Environmental Management*}

The City of San Jose, with a general population of over 800,000 people, is the second largest city in California. The City operates 400 municipal facilities that consume about 150 -million kilowatt-hours annually. Until recently, the few City authorities who investigated energyconservation opportunities were generally decentralized and were often hired to manage a particular facility. Most of the medium and small municipal facilities had no specific conservation program.

In 1990, the City's Office of Environmental Management began to focus on energy conservation programs and projects that targeted municipal facilities for which there were no specific resources for implementing energy conservation projects. The City's growing Capital Improvement Program (CIP) provided an annual funding base to expedite qualifying projects. Coordination of energy-conservation projects tightened even further under this DSB program. An audited list of energy-saving opportunities at more than 30 facilities and the prospect of receiving an attractive revenue stream, gave the momentum to establish multi-department coordination in implementing energy conservation projects.

\section{Project Development and Application}

The City's objective in the DSB project was the maximum penetration of energy-conservation measures into both community and municipal facilities. Our procedure to do this included team building, soliciting of bidding co-participants, interpretation of PG\&E's bidding parameters, scenario-driven cost/benefit analysis, and bid preparation.

\section{Team Bullding}

The City of San Jose already had the staff resources to provide simple costing and savings analysis of conservation opportunities through basic energy auditing. Through the Local Government Assistance Program, the California Energy Commission (CEC) assisted in auditing more involved or complicated measures.

The complexity of a DSB warranted selecting a consultant and expanding our staff to include a dedicated staff person. Our team eventually grew to include a program manager, a dedicated assistant, a consultant, and a five-member advisory panel of City staff members.

\section{Soliciting of Bidding Co-participants}

Typically, a city would participate in DSB to bid solely on behalf of its own facilities. The City of San Jose wanted to pursue an innovative approach: achisving maximum penetration by taking an active brokering role in the community and preparing a bid as a partnership. For maximum penetration of energy conservation, the City got the idea of working with the following co-participants:

\footnotetext{
"In June 1993 the City of San Jose reorganized their offices and the Office of Environmental Management became the Environmental Services Department.
} 
Large commercial/industrial facilities

Multi-family residential dwelling units

Small commercial buildings

Other constituents previously involved in San Jose's energy programs

The DSB team spent about $15 \%$ of their time investigating scenarios involving co-participants and developing resources to do so.

\section{Interpretation of PG\&E's Bidding Parameters}

Correct interpretation of the elements of a DSB program was essential to compete in this program because the DSB process was quite different from that of rebate applicaticns. A consultant was retained to help with interpreting this and other DSB programs. Although our team spent more than $50 \%$ of the time in interpreting the terms, equations, and qualifications of this RFP, many of the key factors remained unclear until after the pre-release conference held just before the Request for DSB Proposals was sent out. Attending all meetings regarding the development and explanations of the bidding parameters was judged as primarily important.

Lack of clear understanding of what made a bid competitive, and what revenue stream might be expected, forced us to rely on assumptions. These assumptions formed the basis for choosing between what was possible, and what was not, under this program. A strong focus was applied to clarifying these assumptions early in the process and before settling on a participation scenario.

Conflicting motives could have bern expressed within interdependent evaluation criteria. Confusion arose from this conflict and affected attempts to optimize the competitiveness of a bid. Any analysis of scenarios of participation or of the measures and plans of the proposal itself, would require extensive review. This review was predicated on cost/benefit and risk/benefit analysis.

\section{Scenario-Driven Cost-Benefit Analysis}

The potential for forming partnerships with other utility customers and independent third parties under this DSB program provided many options to investigate. This investigation and weighing the costs, benefits, and risks for each scenario, kept our staff busy with detailed analysis. Much of the work done in the early stages of the study centered around determining the net benefits of choosing a particular route compared to others. With available rebate programs as a baseline for comparison, participation scenarios were judged worthy if, among other things, they produced more benefit (net present value) than a rebate.

Delays in the utility's RFP process allowed us time to explore many such avenues and their associated cost/risk/benefit ramifications. Our exploration of options required involvement of the City Attorney, Public Works, General Services, City Manager's Office (Deputy City Manager), and the Budget Office. Each of these departments would be affected by a winning DSB proposal and would need to approve the final content of the proposal package before it was submitted. Therefore, coordination with each department early in the process was essential. 
Eventually, this coordinated exploration determined certain minimum thresholds that would have to be met to proceed. Legal barriers, such as conflicts of interest and liability exposures, plagued some scenarios from the start. Budgetary constraints set parameters for the simplification and down-sizing of the remaining choices. The City narrowed the options for participation down to three. Each of these would not be without its problems.

\section{Bid Preparation}

The possibility existed for the City of San Jose to determine that, all in all, entering into a contract under the PowerSaving Partners program might not be a prudent decision. At times, our analysis of the marginal benefits of this complex program compared to the simple rebate program caused us to strongly consider not submitting a bid. Realizing, however, that producing and submitting a proposal did not necessarily bind us to a contract with PG\&E allowed us to proceed on an investigative basis. In this way, our objective to submit a bid was met.

Preparing to submit a bid to this Request for DSB Proposals brought up two somewhat conflicting objectives. The City did not want to submit a low bid that would result in a contract providing no real benefit over existing rebate programs. However, the City also did not want to submit a bid that was not competitive either.

Our plan required continued assessment of the benefits and risks at every step of the process. To help in meeting the objectives and minimum requirements for continuing to pursue a DSB contract, we established benefit thresholds. If our proposal did not produce at least four times the benefit of currently available rebate programs (in net present value terms), then we would oniy proceed on an academic basis.

\section{Defining the Case Study}

Our objective of producing a case study was complicated by delays throughout the year. The timing of the release of the PowerSaving Partners extended the program beyond the limits of the Urban Consortium grant proposal. Thus, this case study's objectives to cover the preparation, submittal, and negotiation of this proposal will not be fully realized. Contract negotiations could extend until August 1993.

Due to the timing constraints of the grant funds dedicated to producing this case-study report, our objectives were limited to cover the process up until the time of this report. 


\section{CHAPTER 3-Setting the Context for Participation: Rebates vs Demand Side Bidding}

Applying for and obtaining utility incentives under the DSB program was much more complex than that for traditional rebate programs in the following areas:

1. The application for incentives was submitted via a competitive sealed bid;

2. There were no assurances or guarantees that a bid would be successful or that bidpreparation costs would be recouped;

3. The bidder was required to provide conserved-energy performance guarantees;

4. Partnerships and/or co-participation agencies between prospective bidders and utility customers were possible;

5. Analyses of costs and benefits went far beyond simple payback calculations and ventured into PG\&E/CPUC's version of the Utility Cost (UC) test and the Total Resource Cost (TRC) test;

6. Projects were required to include a measurement and verification plan to strictly verify and document savings annually over seven to ten years;

7. Complex economic calculations promoted the use of "rule-of-thumb" variables during initial strategy formation, general decision-making, and auditing;

8. Project implementation was required to be completed within a three-year period;

9. Many City departments would have to be "educated" to understand the complex DSB process-with its corresponding unique costs, benefits, and risks-to gain interdepartmental coordination and support.

Surely, the benefits of traditional "proof-of-purchase" and "verification-of-installation" rebate programs are found in their simplicity.

\section{Setting Minimum Benefit Thresholds for Continued Participation}

The base-line for comparison of all potential scenarios under the DSB project was PG\&E's Customized Rebate Program. The 1993 rebate program paid $\$ 0.05$ per $\mathrm{kWh}$ saved in the first year of operation up to $50 \%$ of the project cost. It required an application with a detailed invoice of material and labor expenses, and typically involved a pre- and post-installation inspection. This process had no measurement and verification activities, performance guarantees, competitive applications, contractual timelines, or long-term contract management.

Given the complexity of pursuing the DSB incentive program, certain minimum parameters would have to be met to realize a net benefit over the available rebate program. These parameters aided in deciding:

- the minimum project size;

- the profile of measures included in the bid package;

- the scenario for including other players in the bidding scheme; 
and

- whether or not to participate in bidding at all.

Our first premise for participation was that the value of the contracted bid payments would have to be more than four times the currently available rebates for the same projects. For example, if the rebate for a set of projects would be $\$ 50,000$, then the value of the bid payments would have to be over $\$ 200,000$. This marginal benefit would be required to cover the expense of bid preparation, risk mitigation, and long-term contract management. It would also need to cover the lost revenue from delays in project implementation. A year's delay in implementation under the DSB program would reduce its net benefit by a year's worth of lost utility-bill savings. A risk that was not costed out in our case was the risk of not winning the bid; this factor must also be weighed when bid preparation costs become significant.

For a municipality with limited financial and personnel resources, bid preparation could become an expensive gamble. The cost to local governments for bid preparation, and answering any subsequent clarification questions required by the utility, could range from $\$ 5,000$ to more than $\$ 50,000$. The actual amount is a function of the audits done for proposal development and the expertise in preparing a DSB proposal. Spending over $\$ 50,000$ to prepare a proposal, which may or may not be awarded, is quite a gamble. Of 135 megawatts of proposals submitted to this program, only 20 megawatts would be selected. Even the best ESCOs in the nation realizer! that the chance of winning an award in this program would be questionable.

Our second threshold for participation was that the over-all project size would have to be large enough to produce revenues of more than $\$ 200,000$ over currently available rebates to cover prebid and post-bid overhead and administration expenses. During development of this DSB program, budgetary uncertainties caused us to limit the size of our energy conservation package and select simple, short-term payback projects. Although choosing simple, short-term payback projects increased the potential to meet this threshold, limiting the size of the project reduced it. Third party participation would have to be accounted for in meeting this threshold and could be a net benefit or a net expense.

Our third threshold was that our legal exposure would have to be kept to a minimum. The City of San Jose is a Charter City. Violation of the City Charter would not be acceptable. Municipal governments acting in an ESCO capacity or as a partner to a private, for-profit, business would strain most City policies. However, the liability of performance guarantees were generally held as acceptable. 


\section{CHAPTER 4-Investigation of Participation Scenarios}

\section{Identifying Potential Participation Scenarios}

The PowerSaving Partners RFP allowed for both customer-bidders and third party entrants (ESCOs). With this flexibility, six potential scenarios/relationships in the bidding process became available. These scenarios were:

1. City as a customer bidder I-The City would audit its own facilities and would prepare a proposal to implement a package of measures in selected facilities.

2. City as a customer bidder II-The City would prepare a proposal to implement a Citywide energy conservation program which would affect the City's energy consumption. For example, the City could propose a policy program to convert all T12 fixtures to T8 fixtures during normal periodic lamp changing and lens cleaning. No particular facility and no particular base-case would be identified. All calculations would be estimates from general assum-tions.

3. City as an ESCO-The City would propose to market energy conservation in the private sector of San Jose as a non-profit, third party provider.

4. City uses an ESCO only as a consultant-The City would pay an ESCO to audit facilities, prepare a proposal, handle negotiations with $P G \& E$, and provide contract management services (including measurement and verification activities).

5. City forms a partnership with one or more ESCOs-In partnership, the City and $\mathrm{ESCO}(\mathrm{s})$ combine efforts and pool resources to implement conservation projects and programs in City facilities, as well as market to the private commercial and residential sectors of San Jose.

6. City becomes a client of an ESCO-An ESCO contracts with the City to use City facilities as "host sites" for the ESCO's proposed energy conservation measures.

Each of these scenarios could have had a viable outcome and each scenario supported certain risk/benefit trade-offs. Whenever an ESCO would be involved in the process, some or most of the risk would be transferred from the City and some or most of the benefit would follow with it. Selecting the best scenario for the situation required realistic evaluations of in-house resources (personnel, funding, expertise, etc.), municipal-specific legal restrictions, number and type of projects and/or programs, and willingness to manage and guarantee a utility partnership contract for several years. 
The City of San Jose began the case study with the goal of maximizing the penetration of energy conservation measures in both its own facilities and the community at large. The table below summarizes the possible advantages and disadvantages for each of the six scenarios.

\section{Table 2. Potential participation scenario advantages and disadvantages.}

\begin{tabular}{|c|c|c|}
\hline Scenario & Advantages & Disadvantages \\
\hline 1. Customer bidder I & \begin{tabular}{|l} 
a. Tangible, pre-audited, \\
do-able projects; \\
b. All benefits remain with City \\
(savings \& bid payments); \\
c. Simple relationship with utility \\
(no other players); \\
d. Predictable resource \\
commitments.
\end{tabular} & $\begin{array}{l}\text { a. City takes on all risks, } \\
\text { including bid preparation } \\
\text { costs, contract management } \\
\text { and performance } \\
\text { guarantees; } \\
\text { b. Bid prepared by personnel } \\
\text { not likely to have previous } \\
\text { bidding experience. }\end{array}$ \\
\hline 2. Customer bidder II & $\begin{array}{|ll|}\text { a. } & \text { Simplified proposal; } \\
\text { b. } & \text { All benefits remain with City } \\
& \text { (savings \& bid payments); } \\
\text { c. Simple relationship with utility } \\
\text { (no other players). }\end{array}$ & $\begin{array}{l}\text { a. Must achieve program goals } \\
\text { within three years; } \\
\text { b. Behavior/program } \\
\text { assumptions and variables } \\
\text { are very hard to quantify and } \\
\text { guarantee; } \\
\text { c. City-wide long-term } \\
\text { commitment essential; } \\
\text { d. City takes on all risks, } \\
\text { including bid preparation } \\
\text { costs, contract management } \\
\text { and performance } \\
\text { guarantees. }\end{array}$ \\
\hline 3. City as an ESCO & $\begin{array}{l}\text { a. Penetration into private } \\
\text { sector potentially increasing } \\
\text { impact; } \\
\text { b. Expanded non-profit City } \\
\text { services; } \\
\text { c. City compensated for } \\
\text { services. }\end{array}$ & $\begin{array}{l}\text { a. City takes on large } \\
\text { performance liability } \\
\text { exposure; } \\
\text { b. City competes with private } \\
\text { ESCO sector; } \\
\text { c. Requires a skilled resource } \\
\text { base; } \\
\text { d. Not a traditional role for } \\
\text { government. }\end{array}$ \\
\hline 4. ESCO as a consultant & $\begin{array}{l}\text { a. Benefits remain with City } \\
\text { (savings \& bid payments); } \\
\text { b. City holds contract with } \\
\text { PG\&E: simple relationship } \\
\text { with utility; } \\
\text { c. Protessionally analyzed and } \\
\text { prepared proposal; } \\
\text { d. Straight-forward relationship } \\
\text { with ESCO. }\end{array}$ & $\begin{array}{l}\text { a Cost of ESCO services paid } \\
\text { up-front regardless of award } \\
\text { status; } \\
\text { b. City retains risks, including } \\
\text { bid preparation costs, project } \\
\text { auditing costs, PG\&E and } \\
\text { consultant contract } \\
\text { management, and } \\
\text { performance guarantees; } \\
\text { c. Consultant service can be } \\
\text { redundant to services } \\
\text { provided free by sponsoring } \\
\text { utility. }\end{array}$ \\
\hline
\end{tabular}




\begin{tabular}{|c|c|c|}
\hline Scenario & Advantages & Disadvantages \\
\hline 5. ESCO partnership & $\begin{array}{l}\text { a. Greatest market penetration; } \\
\text { b. Pooled resources and } \\
\text { abilities. }\end{array}$ & $\begin{array}{l}\text { a. Complicated business and } \\
\text { legal relationship; } \\
\text { b. Extensive exposure to } \\
\text { pertormance liabilities; } \\
\text { c. Potential conflicts of interest } \\
\text { arise when public agency } \\
\text { parners with for-profit } \\
\text { businesses. }\end{array}$ \\
\hline $\begin{array}{l}\text { 6. ESCO as an agent } \\
\text { (City as client to third party } \\
\text { provider) }\end{array}$ & $\begin{array}{l}\text { a. Virtually all risks, long-and } \\
\text { short-term, are borne by the } \\
\text { ESCO (ESCO holds contract } \\
\text { with PG\&E); } \\
\text { b. City enjoys suitable financial } \\
\text { return with little irivestment: } \\
\text { c. Bid professionally prepared } \\
\text { yielding a greater chance of } \\
\text { award; } \\
\text { d. ESCO identities and } \\
\text { includes additional projects, } \\
\text { rrivate and public buildings, } \\
\text { increasing penetration of } \\
\text { conservation; } \\
\text { e. ESCO provides financing of } \\
\text { projects; } \\
\text { f. ESCO does not get paid if } \\
\text { bid is not won or if savings } \\
\text { are not produced. }\end{array}$ & $\begin{array}{l}\text { a. Financial benefits are split; } \\
\text { b. ESCO/City contract is } \\
\text { atypical and adds one level of } \\
\text { complexity to bidding } \\
\text { arrangements. }\end{array}$ \\
\hline
\end{tabular}

\section{Determining a Participation Scenario}

The City's goal of maximum penetration of energy conservation fostered the idea of working with co-participants; however, policy, liability, and funding issues limited the project to City facilities only. This would be the typical avenue or a city to participate in DSB-prepare its own bid and bid solely on behalf of its own facilities. Not satisfied with proceeding in a typical fashion, we investigated other possibilities for participation. Through analysis of cost/benefit and risk/benefit ratios, we determined other attractive scenarios:

First choice: Scenario \#6-Become a clienc to a third-party provider (ESCO) and allow Cityowned buildings to become hosts for the ESCO's conservation measures.

Protecting the City from short- and long-term risk became a priority in decision making. For a small investment in personnel to assist in proposal and contract preparation, the City could participate in the program and reap the rewards of installing energy conservation measures with no capital costs. The ESCO would do additional audits, prepare a proposal, secure project funding, submit the proposal, and negotiate a contract with PG\&E upon acceptance. If awarded, the ESCO would manage the ESCO/PG\&E contract during implementation and longterm verification activities. The ESCO's compensation could be tied to achieving a contract with PG\&E by the splitting of bid payments. This performance-based contract would mean that no compensation would be given for a losing bid. An RFQ released by the City of San Jose 
produced five parties interested in only a split of the bid payments as compensation. Determining the exact split became a function of risk assignment.

Second choice: Scenario \#1-Customer-bidder I: City prepares and submits its own bid covering only specific measures in City-owned facilities.

Splitting revenues with an ESCO, as suggested above, could reduce the marginal benefit of this DSB over the available rebate programs to unacceptable levels. Proceeding as a customer-bidder would require dedication of staff resources, and possibly a paid consultant, for producing a bid and managing a contract over seven to ten years. Unfortunately, a losing bid, in this case, would provide no benefit for the expenses incurred during proposal preparation. If these resources were available, and the bid was won, this scenario would maximize the benefits of this program and would provide a far beiter return than the typical rebate for similar projects.

Third choice: Do not submit a bid.

All other scenarios were judged as too risky, of little or no marginal benefit over current rebate programs, or illegal under the City's charter.

\section{Outcome of Scenario Choices}

In pursuit of our first scenario choice, the City released a Request For Qualifications (RFQ) to 28 ESCOs, detailing our interest in becoming a client to an ESCO in this demand side bid. Five responses were received. The winning respondent proposed to prepare, submit, and service the proposal to, and contract with, PG\&E with the City as their client.

A bid payment split of $40 \%$ to the ESCO and $60 \%$ to the City was suggested as a starting point for contract negotiations. This amount would change as a function of assigned risk. For instance, if the City funded the project on its own or took on long-term performance and verification risks, the split would shift in favor of the City. If the ESCO provided financing or took on other risks, the split would shift in favor of the ESCO.

Development of a contract with the winning respondent was cut short when PG\&E released its RFP on October 15, 1992. At the time of the release, the ESCO/City contract negotiations had barely started. With three months to prepare and submit a bid, the City was losing confidence in the viability and benefits of pursuing an increasingly complex contract with the ESCO. Three months was not enough time to resolve funding issues, finalize ESCO contract negotiations, obtain City Council approval on this complex contract, and prepare a quality bid.

Also at that late time, the City lost one of the key benefits of this ESCO/City relationship. The City had hoped that by bringing a professional ESCO into the picture, additional energy conservation opportunities would be identified beyond what our staff had found. The added value of submitting more identified energy savings to PG\&E would produce enough revenues to offset the participation of the ESCO in the bidding process. However, with no time left to do extra audits, this added value was lost. Benefits of ESCO participation were decreasing rapidly.

With no time left and potential benefits of the ESCO scenario eroding, the City was left with little choice but to terminate pursuit of the ESCO contract and produce the bid on its own. 


\section{The City on Its Own}

In preparing to produce the bid proposal on its own, the City used consultani services (Synergic Resources Corporation) that were previously contracted for assisting in this DSB. Not enough funding remained to have this consultant prepare the bid for us; however, through a series of brief consultations, the main framework of the document and potentially successful project parameters were determined. The make-up of projects and proposal details rested solely on City staff.

During this DSB program process, budgetary shortfalls affected our state, county, and city governments. Long-term resources that could be dedicated to managing this contract were constantly in question. Our staff was required to measure and verify the annual savings each year for seven to ten years. An annual verification report would be essential to determine the bid payment for that year. This would require personnel, or a consultant, with familiarity of the bidding process and the terms of the final contract, to oversee the measurement and verification, to calculate annual savings from data sampling, and to submit the report each year.

On a steep learning curve, the City was able to assemble qualifying projects which produced the long-term savings expected for a competitive price. 


\section{CHAPTER 5-Interpretation of Bid Evaluation Criteria}

This report is limited in the amount of speculation or universal review of demand side bids held by other utilities. We hope, however, that an in-depth analysis and evaluation of the PowerSaving Partners RFP provides some insight and transferable information applicable to all DSB. The PowerSaving Partners RFP was state-of-the-art, and as such, will provide valuable information toward understanding future DSB offerings from PG\&E and other utilities.

The evaluation criteria or attributes were scored separately but often showed interdependent qualities. In other words, a single feature of a proposal could have an effect on more than one evaluation criterion. This section examines each of the seven evaluation criteria or attributes set by the PowerSaving Partners RFP:

$\begin{array}{lr}\text { Economic Attribute } & 45 \% \\ \text { Measurement and Verification Plan Attribute } & 15 \% \\ \text { Program Development Attribute } & 10 \% \\ \text { Marketing Plan Attribute } & 10 \% \\ \text { Compatibility with PG\&E Energy Efficiency Programs Attribute } & 10 \% \\ \text { Comprehensive Package Attribute } & 7 \% \\ \text { Location Attribute } & 3 \%\end{array}$

\section{Economic Attribute (45\%)}

This attribute carried the highest evaluation weight of the seven criteria. The score for this attribute was based on the payback period range of the proposal and ranked by a benefit/cost equation called the Total Resource Cost (TRC) test. Proposals were first separated into two categories based on their discounted payback period for TRC ranking and scoring - those with a payback of less than three years and those with three years or greater.

Our original interpretation of this equation suggested that a higher TRC value would be produced by proposing a smaller bid payment. This logic follows previous DSB offerings that used the Utility Cost (UC) test. With the UC test, a lower bid payment value would produce a more favorable UC value. As the analysis of the TRC unfolded, and the exact meaning of each equation component was examined, we found this was not the case with the TRC test.

The TRC equation, shown below, was the ratio of net marginal costs the utility avoids-by not having to produce the energy saved-to the sum of net costs of the project plus payments to the shareholders. All values were adjusted to present value figures before applying them to the TRC equation.

$$
\text { TRC }=\frac{\text { Total Net Avoided Cost }}{[\text { (Customer Contribution }+ \text { Bid Payment }) \times \text { NTG }]+ \text { Shareholder Earnings }}
$$

Understanding the terms of this equation and how each factor of a proposal affected the ratio was critical to producing an optimized and competitive bid. Definitions of these terms (see Appendix B: Terms and Definitions) and a software package that automatically calculated the TRC were provided with the PowerSaving Partners RFP. However, analysis of the mathematics 
was essential to figuring out the best way to produce a qualifying bid. Each term is defined separately below, then analyzed by describing its affect on the final TRC value.

\section{Total Net Avoided Cost (TNAC)}

The TNAC is considered the "benefit" portion of this benefit/cost equation. It is the numerator and can be further represented by this expanded form:

\section{TNAC $=$ NTG $\times \sum_{1994-2003 ?}$ (Power Savings $\times$ Avoided Costs)}

The Net-to-Gross coefficient (NTG) equals 1.0 if the proposal's project payback period is greater than two years; otherwise NTG $=0.7$. This factor assumes that $30 \%$ of the proposed projects with a payback period of under two years would be implemented without this incentive program. Projects applying to an incentive program that would be done even without an incentive program are called cream-skim. The NTG coefficient would account for free-riders and discourage cream skimming proposals. However, a change in NTG from 1.0 to 0.7 is highly diluted in the TRC equation because this coefficient is in the numerator as well as the denominator of the TRC equation. This $30 \%$ change in the NTG value has less than a $5 \%$ effect on the final TRC outcome. However, the associated change in proposed projects-to projects that provide a less than 2-year payback-could more than double the TRC value.

The term (power savings $\times$ avoided cost) is a simplified representation of this part of the equation. For the actual value it represents, the capacity savings $(\mathrm{kW})$ of the proposal must be distributed to reflect its impact in each time-of-use (TOU) period over each year. The same is done for energy savings impacts. Distributing impacts into TOU periods is done by using the utility's load impact coefficients called H-factors as prescribed by the PG\&E RFP. The table below represents the projection of the power savings of a proposed lighting project into each TOU period.

Table 3. Projected power savings of proposed lighting retrofits.

\begin{tabular}{|llllll|}
\hline \multicolumn{7}{|c|}{$\begin{array}{l}\text { SUMMER } \\
\text { ON-PEAK }\end{array}$} & SUMMER & SUMMER & WINTER & WINTER \\
\hline Lighting Retrofit (1994 installation) & SUR & OFF-PEAK & PART-PEAK OFF-PEAK \\
\hline CAPACITY & 5.14 & 5.14 & 4.06 & 6.04 & 5.08 \\
ENERGY & 632.93 & 617.01 & 1011.93 & 1561.78 & 1312.35 \\
\hline H-factors: Commercial; Office; Lighting
\end{tabular}

(Retrofit Savings $=5.14 \mathrm{~kW} \& 5,136 \mathrm{kWh}$ annually)

Once this distribution is made, each impact is multiplied by what the marginal savings (avoided costs) a kilowatt or a kilowatt-hour is worth in each TOU period for each year the savings are claimed. Excerpts from PG\&E's Marginal Avoided Cost tables are shown below. 


\section{Marginal Avoided Power Costs}

\section{Table 4. Marginal avoided power costs.}

(Secondary Distribution)

\begin{tabular}{|llllll|}
\hline & $\begin{array}{l}\text { SUMMER } \\
\text { ON-PEAK }\end{array}$ & $\begin{array}{l}\text { SUMMER } \\
\text { PART-PEAK }\end{array}$ & $\begin{array}{l}\text { SUMMER } \\
\text { OFF-PEAK }\end{array}$ & $\begin{array}{l}\text { WINTER } \\
\text { PART-PEAK }\end{array}$ & $\begin{array}{l}\text { WINTER } \\
\text { OFF-PEAK }\end{array}$ \\
\cline { 2 - 6 } Capacity $(\$ / \mathrm{kW})$ & & & & & \\
\cline { 1 - 6 } 1994 & 50.51 & 21.07 & 5.70 & 23.21 & 3.51 \\
1995 & 52.99 & 21.99 & 5.95 & 24.08 & 3.66 \\
Energy (\$/kWh) & & & & & \\
\cline { 1 - 3 } 1994 & 0.05055 & 0.04124 & 0.03571 & 0.05499 & 0.04254 \\
1995 & 0.05496 & 0.04490 & 0.03753 & 0.05763 & 0.04316 \\
\hline
\end{tabular}

\section{Examples}

The avoided capacity cost for this lighting retrofit in 1994 Summer On-peak would be:

$$
\begin{array}{lll}
\text { Marginal Cost } & \times \text { Savings Impact } & =\text { Avoided Cost } \\
\$ 50.51 / \mathrm{kW} & \times 5.14 \mathrm{~kW} & =\$ 259.62
\end{array}
$$

The avoided energy cost for this lighting retrofit in 1995 Summer Partial-peak would be:

$$
\begin{aligned}
& \text { Marginal Cost } \times \text { Savings Impact }=\text { Avoided Cost } \\
& \$ 0.04490 / \mathrm{kWh} \times 617.01 \mathrm{kWh}=\$ 27.70
\end{aligned}
$$

The sum of all the avoided costs for each TOU period for the life of the project equals the Total Avoided Cost. Although calculating this by hand would take a long time, the software provided with the RFP calculates this for the bidder and multiplies it by the NTG to get the Total Net Avoided Cost (TNAC).

When the TNAC increases, the TRC also increases. Therefore, increasing the TNAC improves the economic attribute score. To increase the TNAC, projects that provide power savings during summer on-peak must be emphasized over projects with off-peak impacts. When compared to indoor office-lighting retrofits, an outdoor lighting retrofit (whose savings occur off-peak) adversely affects a proposal's TRC final outcome.

For the lighting retrofit example above, the impact from capacity savings is noticeably greater than from energy savings. This emphasis on capacity occurs for measures/projects with low annual operating hours. The above retrofit is in a building with only 1,000 hours of annual operation. Energy savings would usually overtake capacity savings when annual operating hours were:

1. More than 2,300 hours for commercial building lighting 
2. More than 1,500 hours for commercial building air conditioning.

Projects with high operating hours, overlapping summer on-peak, are good choices for improving TRC results.

\section{Customer Contribution Plus Bid Payment for Total Cost}

Bid Payment is the net present value of the sum of all the payments to the winning bidder. Customer Contribution is described as any costs incurred or funds expended by host customer in connection with the implementation at host facilities of the proposed program, such as auditing, design, materials, labor, management, financing, and measurement and verification. This description of customer contribution can be interpreted to mean total project cost, but this is not the case. As noted in the answer to question 105 of the PowerSaving Partners Q\&A, for the customer bidder :

\section{Customer Contribution + Bid Payment $=$ Total Project Cost}

Interpreted mathematically, the customer contribution is not equal to the project cost. It is the difference between the total net present value of the yearly projects costs and the yearly bid payments. What this means to the customer bidder is that the bid payment does not affect the TRC unless the bid payment exceeds the Project Cost. The table below shows an example where a proposal has a project cost of $\$ 200,000$ and a TRC of 1.5 .

Table 5. Customer contribution plus bid payment for total project cost.

\begin{tabular}{|lll|}
\hline $\begin{array}{l}\text { Customer } \\
\text { Contribution }\end{array}$ & Bid Payment & TRC \\
\hline$\$ 200,000$ & $\$ 0$ & 1.5 \\
$\$ 100,000$ & $\$ 100,000$ & 1.5 \\
$\$ 0$ & $\$ 200,000$ & 1.5 \\
\hline
\end{tabular}

All else being equal, the level of customer contribution vs utility contribution does not affect the TRC results. A proposal asking for a larger bid-payment contribution does not sacrifice TRC results.

Optimizing the value of this part of the TRC equation is a function of project cost, not bid payment. If the TNAC (the numerator) is held constant, a lower project cost boosts the TRC result. Projects that provide significant energy and capacity savings for a low cost produce the best TRCs. Lighting, energy management system, variable speed drive, and thermal energy storage projects are typically on this list.

Caution must be used to weigh the effect on other evaluation attributes of proposing low-cost, high-saving projects. The other evaluation attribute most directly affected by cream-skim type projects is Comprehensiveness. However, given the $45 \%$ weight for Economics versus the 7\% weight for Comprehensiveness, there seems to be an overwhelming incentive to cream-skim. Although the utility strongly urges the bidders away from cream-skimming type bids, the economics benefit tremendously by doing so. 


\section{Shareholder Earnings}

The remaining term of the TRC equation is shareholder earnings. This term, also in the denominator as a cost, represents the following mathematical description.

\section{Shareholder Earnings = \\ $.079 \times[$ TNAC $-[(.25 \times$ Bld Payment $)+(.50 \times$ NTG $\times($ Bid Payment + Customer Contribution $))]]$}

Changes made to a bid proposal affect the value of the shareholder earnings. However, these effects are reduced by the 0.079 coefficient. In other words, a $10 \%$ change in the TNAC represents a $0.79 \%$ change in shareholder earnings. This term in the equation merely represents a link between PowerSaving Partners' investment in energy efficiency and the profit PG\&E earns. To the bidder, its effects on TRC outcome are negligible.

\section{Utility Cost Test}

Higher bid payments did affect the Utility Cost (UC) test which was used as a tie-breaker in this request for DSB proposals. Other DSB offerings in the nation have traditionally used the UC test and not the TRC. The UC test took into account the bid payment, but ignored the customer contribution and project cost. Hence, it was not a total resource cost test.

$$
U C=\frac{\text { TNAC }}{\text { Bid Payment }+ \text { Shareholder Earnings }}
$$

The importance of optimizing the UC results was lessened by the unlikelihood of a tie score between bids. Even if two bids did tie, the acceptance of one would have to lead to the denial of the other for it to make any difference. The likelihood of two bids tied and on the threshold of acceptance is small. We chose to pay little attention to the UC test results.

\section{Measurement and Verification (M\&V) Attribute (15\%)}

Bidders were required to develop an $M \& V$ plan that demonstrated that the proposed savings would be measured and verified using practical and statistically valid methods. This plan was required to document all procedures used to confirm installation and savings of each measure, the annual measurement and verification procedures, and operation and maintenance.

Two major considerations for developing an M\&V plan are:

1. the extent the payments are linked to the performance of the measures; and

2. the relative appropriateness and sophistication of the plan to the measures proposed.

PG\&E strongly preferred a linkage between payments and performance. A direct linkage was interpreted to mean that a $10 \%$ shortfall in expected savings would result in a corresponding $10 \%$ reduction in bid payments. Proposals whose annual payments were not linked to savings performance would not score well in this catigory. 
The relative appropriateness of the $M \& V$ plan was an important factor for this attribute and the Economic Attribute. The cost of $M \& V$ was part of the overall project cost. An M\&V plan that would cost $\$ 5,000$ to implement on a project that cost only $\$ 10,000$ to install would be obviously inappropriate. $M \& V$ methods would vary according to the mix of measures in a proposal. An M\&V plan that incurred total costs between 5-10\% of the implementation cost over the ten year contract seemed most reasonable for lighting measures. The cost ratio for thermal energy storage would be higher for building load and yearly weather changes.

Aside from the major points listed above, optimizing this attribute required completeness and clarity in presenting the procedures used to establish verified savings. Methods for measuring and verifying savings are well documented in energy conservation literature. A good M\&V plan will comply with generally accepted engineering and statistical standards. Given the weight of this attribute and its affect on the overall project cost, bidders should give a lot of attention to optimizing the $M \& V$ plan.

\section{Program Development Attribute (10\%)}

PG\&E wanted project proposals that had a better than reasonable chance of actual implementation. The project was required to be supported by a concrete plan to fund or finance its implementation and it was required to have a team of players able to implement and maintain the project through the contract period. In this section, PG\&E wanted financial statements and resumes.

Financing plans that clearly showed detailed cash flow information and identified secured sources of funding were likely to score highest in this area. For a municipality, funds would often come from a municipal improvement account of the General Fund. This could become a circular quandary. The hurdle involved with securing municipal funds would be convincing the funding authorities to make a commitment, before the fact, to fund based on a less than 50/50 chance the proposal would get awarded. At the same time, scoring well in this attribute so that the proposal could win required a tangible commitment of funds to cover implementation.

Financing alternatives could eliminate this funding quandary for municipal governments, but the cost of issuance and interest would increase the overall cost of the project. Increasing the overall cost of the project would directly affect the TRC value of the proposal. A written letter of financing commitment would increase the score in this attribute, but would detract from the economic attribute.

Since a customer-bidder would avoid having to market energy efficiency to utility customers, our evaluation of the development team and management plan emphasized technical experience and support functions. To optimize the score for this attribute, previous energy project descriptions were detailed to include:

- types of measures installed;

- types of facilities;

- project costs;

- approximate energy savings achieved;

and 
- the phone numbers of references familiar with the projects. Naming our utility representative seemed to be one of the best references for this.

\section{Marketing Plan Attribute (10\%)}

Customer-bidders who could substantiate their authority to implement energy efficient projects at the sites proposed would score well in this attribute. Expounding on municipal organization and the commitment of these facilities to follow this authority would not be wasted effort. Without specific acknowledgment of this authority or commitment, the utility would consider their participation as voluntary.

\section{Compatibility Attribute (10\%)}

One of PG\&E's goals in issuing the PowerSaving Partners RFP was to enhance and supplement their current energy conservation market coverage. Proposals that interfered or competed with existing programs would undermine this goal. Proposals that were shown to be compatible or complementary to existing PG\&E DSM programs would score highest in this attribute.

The ways in which a customer-bidder proposal could be shown to be compatible or complementary to current programs would be:

1. Offering different delivery mechanisms, such as shared revenues/savings with the host facilities or other financial arrangements, to improve the overall effectiveness of producing long-term persistent savings;

2. Proposing projects in sectors not covered or not fully covered by existing programs. From a municipal government standpoint, cross-sector, non-sector or ill-defined building sectors were common. For example: firestations were not specifically residential or commercial; community and senior centers were not specifically commercial or schools; and, sports and entertainment facilities were simply not specified.

3. Including measures not covered by other utility programs. PG\&E's program provided rebates for: refrigerators, freezers, washers, dryers, air conditioners, and other common appliances. The City of San Jose's kiln replacement was an example of a measure not covered.

\section{Comprehensiveness Attribute (7\%)}

This attribute encouraged the installation of a wide variety of energy efficiency technologies. By installing all economically viable measures at one time, the number of efficiency opportunities bypassed would be greatly reduced. Efficiency measures bypassed would become lost opportunities. By focusing only on the least expensive modifications at each site, many such lost opportunities would be created.

The principle of comprehensiveness was broken down into two categories: depth and width. The width of a proposal was judged by the spectrum of end-use technologies installed at a particular facility. If several types of measures were proposed-such as HVAC, lighting, refrigeration and motors-then the proposal rated well in the width evaluation. The depth of a proposal was judged by the extent to which each end-use was approached. A lighting proposal 
with depth would include converting all incandescents to fluorescents, converting to T-8 lamps with electronic ballasts, clean or replace lenses, and install lighting level or occupancy controls.

\section{Location Attribute (3\%)}

The location attribute attempted to reward proposals for specifically targeting areas where the utility had identified potential for additional cost savings in the distribution and transmission of electricity. For municipalities, and many customer-bidders, the geographic location of the target facilities is preset. The three alternative proposals for customer-bidders were:

1. Facility location completely coincides with a distribution/transmission benefit area and therefore the proposal qualifies for location consideration;

2. Facility location does not coincide with a distribution/transmission benefit area and therefore the proposal does not qualify for location consideration; or

3. Part of the facility location coincides with a distribution/transmission benefit area, in which case the proposal can be enhanced by selecting facilities in the coincident area.

\section{Interdependent Evaluation Criteria}

Several of the evaluation attributes were mutually affected by the elements of a proposal. However, the most dramatic of these ties was between the Economic and Comprehensiveness attributes. These two attributes were found to be antagonistic and to promote conflicting goals in their optimization. Again, the primary goal of the Economic attribute (weighted 45\%) was to provide the highest on-peak savings for the lowest total cost. The goal of the Comprehensiveness attribute (weighted 7\%) was to avoid lost opportunities by installing a full spectrum of end-use technologies at a variety of facilities, not just installing the low-cost, high payback projects. With an evaluation weight of $45 \%$, the Economic attribute should receive preference in structuring a proposal.

This antagonistic effect could occur while pursuing either the width or the depth of a proposal. For a proposal to have width, several end-use technologies should be installed in a certain facility. A proposal with only T-8 lighting retrofits (less than 2-year payback) generally would produce a much higher TRC value than a proposal with T-8 retrofits and chiller replacements (greater than 2-year payback). The project implementation cost per unit of savings increased dramatically with the addition of most HVAC measures: longer payback, increased engineering, complex auditing, complex pre- and post-implementation measurement and verification. If total proposal costs can be kept down, there are other technologies that could have a fast payback (i.e., variable speed drives, energy management systems, thermal energy storage) and could provide an exception to the conflict.

For comprehensive depth, the concept of diminishing returns came into play by adding depth to the low-cost, high-savings, core project. This seemed to indicate that pursuing depth would be contrary to optimizing the economic character of the proposal. For example, in a four-lamp, $2 \times 4$ troffer fixture, merely changing out 40-watt lamps for 34-watt lamps was economically better (cost to produce a $\mathrm{kW}$ of savings) than retrofitting to T-8 lamps with electronic ballast technology.

Exceptions existed in this category also. The example of depth provided in the PowerSaving Partners RFP is a good example here. It suggested that adding lighting controls to a core T-8 
retrofit increased depth. If one occupancy sensor controled four or more fixtures, this increased depth made economic sense in a commercial office setting.

Optimization of the Measurement and Verification Attribute (15\%) of proposal evaluation could also conflict with the Economic Attribute. Extensive measurement and verification plans could increase the total proposal cost to the detriment of the TRC result. The PowerSaving Partners RFP seemed to require keeping M\&V appropriate to the technology. Since there were no strict guidelines available to detail what constituted an "appropriate" M\&V plan, it was not clear what marginal effect an increase in $M \& V$ coverage had on the scoring of this attribute. For instance, a $\$ 10,000$ increase in $M \& V$ costs for a project cost of $\$ 500,000$ represented less than a $2 \%$ change in the TRC, but may have made a huge difference in M\&V scoring.

Another attribute link could come up for a customer-bidder municipality. Funding/budget commitmonts are difficult to arrange for a proposal that may or may not be accepted. A proposal that would be required to turn to financing commitments to bring certainty to the financing plan of a proposal would in turn pay more for the projects. For uncertain funding ability, a written letter of financing commitment would increase the score in this attribute, but the cost of financing would detract from the economic attribute.

Bidders must use caution when optimizing these types of evaluation criteria. Decisions are often easy to make when the interrelation of attributes is well understood. There were other, more subtle, links between attributes; however, with economics carrying a $45 \%$ weight in this case, the focus had to certainly lie there. 


\section{CHAPTER 6-Analysis of the City of San Jose's Proposal}

\section{The Original Proposal}

The City's original bid, delivered to PG\&E on January 15, 1993, contained a proposal for 530 $\mathrm{kW}$ of capacity savings and $714,000 \mathrm{kWh}$ of energy savings for a total of about $\$ 430,000$ in project costs. It contained several lighting retrofits, ' pottery kiln replacement, and three interactive HVAC measures. The City proposed to implement these measures over two years in 30 of its own facilities, which included firestations, senior centers, community centers, service yards, the Center of Performing Arts building, police athletic building, and two main City Hall buildings.

At the first stage of PG\&E's selection process, the City's bid showed two minor deficiencies. These deficiencies were remedied easily with a one-page letter that corrected a mistaken reference and an M\&V oversight.

\section{Extensive Clarification Required}

The second stage of PG\&E's selection process called for clarification of any and all proposal sections that were found to be less than adequate for a full score in that attribute. This process was much more extensive. The City's proposal received over 40 questions seeking to clarify financing commitments, savings calculations, measurement and verification procedures, development team histories, Location Attribute claims, project cost breakdowns, and more. Power savings figures, and other components of the proposal, not sufficiently clarified either received a zero or values would reset to PG\&E default values: either of these alternatives could sacrifice the competitiveness of the proposal.

Given ten working days to respond to the clarification questions, we realized that the City's proposal required some simplification. The estimated savings for the HVAC measures presented in the original bid became a serious problem. In calculating the energy figures, savings were inadvertently double counted. Resetting the figures to show a valid savings for the three interactive measures reduced the net benefit of including them in the proposal. The project costs stayed the same but the savings went down.

The net benefit to the proposal was further reduced by failing to claim an acceptable coincidence factor. A project whose savings do not completely overlap summer on-peak, must claim a coincidence factor that describes the fraction of overlap. In the City's case, each HVAC measure provided 400 annual hours of savings. PG\&E assumed HVAC measures must produce capacity savings at least 1600 hours annually to achieve a coincidence factor of 1.00 . A coincidence factor of $0.25(400 \div 1600)$ unacceptably reduced the estimated savings for these projects; so. the HVAC measures were dropped from our proposal.

\section{Substitutions to the Original Proposal}

Fortunately, PCi\&E allowed for project substitution if they fell within certain parameters. We chose to replace the comprehensiveness motivated HVAC measures with $78 \mathrm{~kW}$ of T-8 lighting retrofit projects. This move to lighting retrofits must have destroyed most of the comprehensiveness score we managed to get by having three HVAC measures. The new TRC outcome was expected to make up for the loss. 
The final form of the City's bid seemed to differ only slightly from the first submittal. The differences arose mainly from making a major substitution and clarifying minor points in most other sections. Many of the original proposal figures were based on errors and should be discounted as inaccurate. The figures presented after the substitutions were made were judged to be highly accurate. The table below presents the summary figures for conparison.

Table 6. Summary of differences between City's original and final proposals.

\begin{tabular}{|lll|}
\hline Category & Original Proposal ** & Final Proposal \\
\hline Capacity savings & $530 \mathrm{~kW}$ & $287 \mathrm{~kW}$ \\
Energy savings & $714,000 \mathrm{kWh}$ & $1,070,000 \mathrm{kWh}$ \\
Cost of implementation (nominal) & $\$ 410,000$ & $\$ 375,000$ \\
Cost of implementation (NPV) & $\$ 311,000$ & $\$ 283,000$ \\
Discounted payback period & 4.43 years & 3.82 years \\
Cost per kW (average) & $\$ 775 / \mathrm{kW}$ & $\$ 1,300 / \mathrm{kW}$ \\
Bid payments based on: & $85 \%$ of avoided costs & $80 \%$ of avoided costs \\
Value of bid payments (nominal) & $\$ 413,000$ & $\$ 471,000$ \\
Value of bid payments (NPV) & $\$ 226,000$ & $\$ 220,000$ \\
TRC value & 2.38 & 2.13 \\
UC value & 3.11 & 2.65 \\
\hline
\end{tabular}

** Original proposal statistics based on erroneous savings figures

\section{Analysis of the City's Proposal}

It was difficult to accurately judge the quality of the City's proposal. The RFP itself, and the interpretation described in this case study, provided some basis from which to conduct a self evaluation. The inadequacy of this approach was in the tremendous variety in the types of bids submitted. Our self-evaluation of the City's proposal did not venture far beyond the customerbidder perspective and therefore lacked total perspective.

Some decided advantages existed for the customer-bidder over third party bids. Customerbidder proposals have the immediate advantage in two evaluation criteria. If the customerbidder was bidding projects in self-owned facilities, then the Marketing Plan Attribute would undoubtedly score well. Lacking a need for extensive marketing to fulfill savings pledges, a customer-bidder would have an advantage in Program Development. This is particularly the case when funding and experience would be present. For municipalities, the Program Development attribute would be further augmented by the stability of the parties involved and the security placed on a bid that proposed tangible, pre-audited measures. 
The following table summarizes our self evaluation of each of the criteria.

Table 7. Summary of self-evaluation of the City's original and final proposals.

\begin{tabular}{|lll|}
\hline Category & Original Proposal & Final Proposal \\
\hline Economic Attribute & good ** & good \\
M\&V & complex/average & simple/good \\
Marketing Plan & customer-bidder & customer-bidder \\
Program Development & excellent & excellent \\
Compatibility & good/excellent & good/excellent \\
Comprehensiveness & fair & poor \\
Location Attribute & good & good \\
\hline
\end{tabular}

"* Original economic attribute based on incorrect savings figures.

The original bid did not rate well once the savings figures for the HVAC measures were corrected. The Economic Attribute was affected most by the correction and would probably rate poor if it were artually calculated out. Measurement and verification of the HVAC measures increased the overall complexity of this category. The City's M\&V plan for these measures fell under heavy fire during the clarification stage; thus, another reason to eliminate them.

The Economic Attribute of the final proposal was judged to be very good. Our proposal had a discounted payback of over three years, and as a result would be scored against others in the over three year payback category. The City's bid probably faired well in this group with a 2.13 TRC value.

Attempting to optimize the Economic Attribute, the City capitalized on three strategies. Development of these strategies arose when City staff used the software provided by PG\&E to run some elemental changes and to record their effects. The computer results indicated that it was difficult to obtain a TRC of more than 2.00 unless there were many cream-skim projects. The first strategy sought to select measures that showed a high energy savings to project cost ratio. Although some of these projects were included in the proposal, we carefully excluded obvious cream-skim and provided some balance by adding longer payback measures. This strategy discounted the value of pursuing a strong score in the Comprehensiveness Attribute.

The computer runs also revealed a second method of selecting projects to optimize the TRC value. Projects with a high-capacity savings coincident with summer on-peak and having a low energy savings component due to abbreviated hours of operation produced good avoided-cost figures (TNAC). Since payback was a function of energy savings (kWh), including lower cost, high-capacity savings projects boosted the TRC without appearing to be a cream-skim project.

The third strategy for optimizing the Economic Attribute called for reporting the lowest estimates of project implementation costs. Penalty for under-estimating project costs was acceptable-one dollar of bid payment sacrificed for every over-cost dollar. Lower-range cost estimates were selected to boost the TRC. We carefully avoided misrepresenting cost figures. 
The City of San Jose, like many other municipalities, used CEC consultants to set up and perform Measurement and Verification activities. Although switching to almost all lighting retrofits simplified this section of the proposal, the clarification questions left some doubt about our ability to meet PG\&E expectations. For the Measurement and Verification Attribute, the self-evaluation score was tentative.

Under the Program Development Attribute, the City of San Jose's award-winning participation in a wide variety of energy conservation programs gave its proposal a good edge. The development team, which included the many departments involved, was strong. Increasing the financing plan score of this attribute was tricky due to our inability to get a funding commitment on a tentative project; however, assurances of funding were given.

The Compatibility Attribute was difficult to judge. Implementation of the City's bid did not eliminate or compete with existing DSM programs, but overlapped them somewhat. The City's proposal asserted that the current rebate programs had not offered enough incentive for prior installations of these measures, and therefore this proposal under the PowerSaving Partners program augmented existing programs.

From a municipal government standpoint, cross-sector, non-sector, or ill-defined building sectors were common. For example: firestations were not specifically residential or commercial; community and senior centers were not specifically commercial or schools; and, sports and entertainment facilities were not specified. By including these types of measures, we expected a good rating in this category.

The Comprehensiveness Attribute suffered from our substitution of another lighting retrofit project for the HVAC measures. Before the substitution, the City's proposal was only judged to be fair. After all, the proposal was neither particularly deep nor particularly wide. By devoting more time to review existing audits and to do others, the City might have discovered and included other high-savings, low-cost measures or projects.

The City's proposal scored at least some points in the Location Attribute. The City of San Jose lies completely within a distribution benefit area. However, the transmission benefit area is a subset of the distribution area. None of the facilities in which measures were proposed were located in the transmission benefit area. 


\section{CHAPTER 7-Lessons Learned}

\section{Working Within the Clty Structure}

The constraints of working toward energy conservation under the PowerSaving Partners program were similar to those of traditional efforts with conservation programs and/or projects. These were typically legal constraints on partner relationships and funding constraints on project implementation. These constraints prevented the more idealistic participation scenarios listed in Chapter 4 of this report. Additionally, requirements for extensive interdepartmental coordination, combined with a rigid RFP timeline, eventually led us to simplify every component of the proposal.

Because of a statewide budget crisis, the DSB proposal team was not able to accurately assess the City's financial commitment to energy conservation projects. Being unable to assess the funding support for implementing the projects caused us to scale down project sizes. Scaling down the project sizes increased the chances of receiving funding during the budget crisis. The largest negative effect of a reduced funding commitment and reduced project size was on the comprehensiveness component of the proposal. Inclusion of several types of high-savings, low-cost measures (i.e., energy management systems and thermal energy storage) became impossible under these conditions.

Another problem affecting the profile of the project and the overall project size was the City's extensive and time-consuming process required for large capital projects. With traditional incentive programs, such as a rebate program, the project implementation schedule would remain flexible to City processes. But with a rigid implementation schedule, projects had to be selected to allow for successful implementation within alloted times. Implementing a thermal energy storage system project could result in a lengthy and unpredictable time schedule. Whereas a lighting retrofit could be done with great predictability and in a short time. The chance of facing performance pesalties under the PowerSaving Partners RFP swayed our decision to exclude many viable, but complex, projects: projects that could enhance the competitiveness, and perhaps the economics, of a DSB proposal.

\section{Re-Assessing the RFP Priorities}

If given another chance to address this request for DSB proposals, many of our initial priorities would resemble more of our final priorities. Exploration of the many participation scenarios presented by this RFP was a high priority early in the proposal development. The opportunity to pioneer new ways to participate in this relatively new DSM arena-attempting to maximize energy conservation in our community - is a worthy endeavor. It is also time consuming. In our case, the assessment and development of participation scenarios shifted attention from the assessment of what would or would not promote a winning bid.

Assessing the evaluation criteria of the Request for DSB Proposals was critical to producing a winning bid-regardless of the participation scenario. A wrong assumption of the economics of a successful bid caused City staff to support a false sense of confidence. Based on historical DSB offerings, we falsely assumed that if a lower bid payment were proposed, then the economic attribute would increase. This seemed intuitively correct, and was factually correct for DSB programs that used the UC test instead of the TRC test for evaluating DSB proposals. 
Because we thought we could just lower the requested bid payment to score well, further assessment of the criteria became secondary to exploration of participation scenarios. 


\section{CHAPTER 8-Recommendations}

Selection of qualifying and do-able projects is key to developing a winning customer-bidder proposal. Emphasis should be put on finding, packaging, and defending those low-cost projects that produce high-savings coincident to the summer on-peak TOU schedule. Time invested in experimenting with the numbers and cost/benefit equations to find the best projects will pay off.

Spend more time on criteria analysis. Correct interpretation of the selection criteria is essential to all the decision processes-including those regarding participation scenarios. Understanding of what actions optimize the score in each element of the RFP will help in resolving conflicting elements in the evaluation attributes. The utility issuing the DSB can be a great source of information. For us, they were very interested in conveying a complete understanding of the elements and their interactions. All bidders/proposers will face similar decisions and tradeoffs, so pay particular attention to the questions that they ask in the open forums.

Make sure that the savings proposed are backed by generally accepted assumptions and engineering-based calculations. Economic attributes are typically weighted very high in DSB offerings. Take care to arrive at defensible numbers. A consultant should be considered if your proposal staff is not skilled in producing and defending savings assumptions and calculations. If savings calculations are not sufficiently documented and defended, the savings value of a particular measure may be set to zero for evaluation scoring.

Measurement and verification requirements are beginning to permeate DSM programs across the nation. Providing an acceptable $M \& V$ plan requires sophisticated knowledge beyond simple auditing. Using a consultant to develop a plan specifically tailored to measure and verify the projects selected for the proposal is better than simply offering a generalized boiler-plate plan that once covered similar projects.

Since submitting a proposal is a gamble under this type of bidding arrangement, make realistic assessments of your ability to spend funds developing the bid and your ability to carry through over the long-term. By setting participation thresholds (such as a minimum return on investment) decisions can be weighed prudently and pragmatically. Work toward producing a bid that considers budgetary and personnel resource constraints. Stretching these constraints to make the bid "look good" is risky and will be noticed by the bid evaluators. 


\section{REFERENCES}

Goldman, Charles, and Wolcott, David, 1990, Demand-Side Bidding: Assessing Current Experience, American Council for an Energy-Efficient Economy, Washington, D.C.

Harding, Steve, 1990, "Beyond Bidding: Performance-Based Programs for Demand-Side Management," Proceedings of the ACEEE 1990 Summer Study on Energy Efficiency In Buildings, American Council for an Energy-Efficient Economy, Washington, D.C.

Kineret, Robert, et. al., 1992, "The PG\&E Model Energy Communities Program: Offsetting Localized T\&D Expenditures with Targeting DSM," Proceedings of the ACEEE 1992 Summer Study on Energy Efficiency and Buildings, Volume 5, American Council for an Energy-Efficient Economy, Washington, D.C.

Pacific Gas and Electric Company, May 1992, Targeting DSM for Transmission and Distribution Benefits: A Case Study of PGEE's Delta District, Electric Power Research Institute, Palo Alto, CA.

Pacific Gas Electric Co., October 1992, PowerSaving Partners: Request for Demand-Side Management Proposals, PG\&E, San Francisco, CA.

Portland General Electric Co., June 1992, DSM Impacts on the TED System: A Macro and Micro Perspective, PGE, Portland, OR.

Raab, Jonathan, 1990, "Is There Room for Integrated Demand-Side Bidding?", Proceedings of the ACEEE 1990 Summer Study on Energy Efficiency In Buildings, American Council for an Energy-Efficient Economy, Washington, D.C.

Schurr, Allan, December 1992, personal communication, Pacific Gas and Electric Company, San Francisco, CA.

Vine, Edward, December 1990, Local Government and Demand-Side Bidding, Lawrence Berkeley Laboratory, Berkeley, CA. 
APPENDIX A: Abbreviations and Acronyms 


\title{
APPENDIX A: Abbreviations and Acronyms
}

\author{
CEC California Energy Commission \\ CIP Capital Improvement Program \\ CPUC California Public Utilities Commission \\ DSM demand side management \\ DSB demand side bid \\ ESCO energy service company \\ HVAC heating, ventilation, air conditioning \\ $\mathrm{kW} \quad$ kilowatt \\ kWh kilowatt-hour \\ MW megawatt \\ $\mathrm{M} \& \mathrm{~V}$ measurement and verification \\ NTG net-to-gross coefficient or ratio \\ O\&M operation and maintenance \\ PG\&E Pacific Gas and Electric Company \\ PSP PowerSaving Partners (PG\&E's program and/or RFP) \\ RFP request for proposals \\ RFQ request for qualifications \\ TNAC total net avoided cost \\ TOU time-of-use \\ TRC total resource cost \\ UC Urban Consortium \\ UC utility cost \\ UCETF Urban Consortium Energy Task Force
}


APPENDIX B: Terms and Definitions 


\section{APPENDIX B: Terms and Definitions}

Avoided cost

Bidder

Bid payment

Capacity savings

Committed operation deadline

Committed operation period

Customer-bidder

Customer contribution

Discounted payback
PG\&E's projection of incremental generation, transmission and distribution capacity, energy and gas costs, as specified in Appendix E of the RFP. These costs will be used to calculate total net avoided cost, the total resource cost test and the utility cost test.

A PG\&E customer or third party who submits a proposal in response to this RFP to provide energy efficiency resources to PG\&E.

Net present value of all the payments to the winning bidder.

Electricity savings, expressed in kilowatts or megawatts, of the proposed program. Capacity savings during a specified time period is defined as the maximum kilowatt or megawatt savings achieved during any 15-minute interval of that time period.

The date on which the committed power savings must be achieved and the program must be fully implemented. The committed operation deadline is three years after the later of the two dates that either:

1) the CPUC approves the winning bidder's executed agreement, or

2) PG\&E notifies the winning bidder that the agreement may be executed.

Beginning at the committed operation deadline and continuing the number of years by the winning bidder in the response package. The maximum committed operation period is seven years.

A bidder who is a PG\&E customer, whose proposed program will be completely installed in facilities that are owned, operated, or leased by the bidder.

Any costs incurred or funds expended, paid in cash or other consideration, by host customers (any customer at whose facility energy efficiency measures are installed) in connection with projects, such as auditing, design, materials, labor, management, financing, or implementation of a program.

Discounted payback (in years) $=$ (gross selling price) $\div$ (annual energy bill savings) 
Energy efficiency

Energy savings

Facility

Front loading

Gas savings

Implementation period

Lost opportunities

Maximum annual capacity savings

Net power savings
In the above equation, the gross selling price equals the net present value over the life of the program of the customer's equivalent retail cost of duplicating the proposed program in its absence (1992\$). The annual energy bill savings equals annual power savings multiplied by the 1992 class average rate (or the customer's actual rate, where the customer is specifically identified).

Technologies, measures, or resources that reduce the consumption of gas or electricity by improving the efficiency of the end use. These technologies, measures, and resources include load management that reduces the consumption of electricity or gas, in addition to shifting demand from peak times to off-peak times.

Electricity savings, expressed in kilowatt-hours, of the proposed program.

A single host customer site that includes one or more buildings that receive electric (and/or gas) service from PG\&E. A proposed program may address one or more facilities.

Expected payments, by PG\&E to winning bidder, during any calendar year, exceeding PG\&E's projected total net avoided cost.

Savings of natural gas, expressed in therms, as a result of the proposed program.

From the date the energy efficiency agreement is executed by PG\&E and winning bidder and approved by the CPUC, to the committed operation deadline. The maximum implementation period for all programs is 3 years.

Occur when measures that can be installed cost-effectively are not offered to customers. Lost opportunity measures are either not cost-effective to install later as single measures, are too difficult to sell to customers later because of the costs of sending personnel out for repeat visits, or are too difficult to sell to customers later because the customer prefers to make all energy efficiency decisions during the initial retrofit.

The maximum capacity savings specified by a proposed program during any 15-minute interval in a calendar year.

Energy, capacity and, if applicable, gas savings multiplied by the net-to-gross ratio. 
Net-to-gross ratio (NTG)

Power savings

Program

Project

Proposal or proposed program

Residual power savings

Shareholder earnings

Short list
The adjustment to power savings reflecting free riders and other reductions or increases to the actual savings of a measure. Values for net-to-gross are specified as a function of measure, market sector and discounted payback as described in the response package. An average NTG ratio of 1.0 is acceptable for programs with a discounted payback greater than or equal to two years. Refer to Appendix M of the RFP for PG\&E's other default NTG ratios.

Energy, capacity, and, if applicable, gas savings.

All of winning bidder's installed and constructed energy efficiency measures, together with all protective and other associated equipment and improvements, maintained and operated by winning bidder as described in the response package. This includes all facilities addressed by winning bidder to produce power savings, excluding associated land, land rights and interests in land. A program may include one or more projects to be implemented in one or more facilities.

The implementation of winning bidder's program in a single facility.

All terms and conditions of the bidder's program described on the forms and tables supplied in the response package, in addition to all supporting documents. A proposed program may include one or more projects to be implemented in one or more facilities.

Power savings resulting from installed energy efficiency measures with useful lives of longer than 10 years. Only winning bidders who select the maximum committed operation period may specify residual power savings, which will be used in calculating the total resource cost test and utility cost test benefit-cost ratios. Winning bidders will not receive payment for residual power savings or be responsible for measuring or verifying these savings.

Incentives to PG\&E shareholders providing a link between investments in energy efficiency program and profit that PG\&E earns.

Shareholders earnings $=$ pre-tax shared savings rate $(7.9 \%)$ $\times[$ Total net avoided cost $-[(25 \% \times$ bid payment $)+(50 \% \times$ NTG $\times$ (bid payment + customer contribution))]]

A list of bidders who have submitted response packages that meet all of the eligibility requirements and minimum thresholds for this RFP and who have been selected for 
Term of agreement

Third party

Total net avoided cost

Total resource cost test (TRC)

Utility cost test (UC)

Winning bidder further negotiation, based on PG\&E's evaluation of the relative merits of their proposed programs.

The energy efficiency agreement will be binding upon execution by PG\&E and winning bidder, and approval by the CPUC, and will remain in effect during the implementation period and the committed operation period.

An energy service company (ESCO) or any other entity that proposes an energy efficiency program for PG\&E's customers.

Net power savings multiplied by avoided costs as specified in Appendix $E$ of the RFP.

The total resource cost test is a test of the costeffectiveness of a proposed program. To be eligible for this RFP, a proposed program must have a TRC benefit-cost ratio of greater than one. In addition, winning bidders must verify that each installed project has a TRC of greater than one. The equation for calculating the TRC benefit-cost ratio is specified below.

TRC $=[$ avoided cost $\times$ power savings $\times$ NTG $]+[$ (bid payment + customer contribution) $\times$ NTG + shareholder earnings]

The utility cost test is a test of the cost-effectiveness of a proposed program. To be eligible for this RFP, a proposed program must have a UC benefit-cost ratio of greater than one. The equation for calculating the UC benefit-cost ratio is specified below:

$\mathrm{UC}=[$ avoided cost $\times$ power savings $\times$ NTG $] \div[$ bid payment + shareholder earnings]

A bidder who has been selected in this RFP to enter into an energy efficiency agreement with PG\&E. 
APPENDIX C: PowerSaving Partners List of Measures 


\section{APPENDIX C: PowerSaving Partners List of Measures}

End results will be measured in the Measurement and Verification (M\&V) portion of the program.

For $2 \times 4 \mathrm{ft}$ fixtures:

- In a two-lamp fixture, replace two existing lamps with two T8 lamps and install an electronic ballast. $20 \mathrm{~W}$ savings per fixture.

- In a three-lamp fixture, remove one lamp and replace existing lamps with two T8 lamps and install one electronic ballast. $60 \mathrm{~W}$ savings per fixture.

- In a four-lamp fixture, remove two lamps and replace existing lamps with two T8 lamps and install one electronic ballast and a reflector. $100 \mathrm{~W}$ savings per fixture.

- In a two T12 lamp fixture, replace lamps with T8 lamps and install an electronic ballast. $20 W$ savings per fixture.

End Result: Each fixture will have two T8 lamps and one electronic ballast.

- In a three T12 lamp fixture, replace lamps with three T8 lamps, replace two magnetic ballasts with one electronic ballast. $36 \mathrm{~W}$ savings per fixture.

End Result: Each fixture will have three T8 lamps and one electronic ballast.

- In a four T12 lamp fixture, replace lamps with four T8 lamps, replace two magnetic ballasts with one electronic ballast. 50W savings per fixture.

End Result: Each fixture will have four T8 lamps and one electronic ballast.

For $4 \times 4 \mathrm{ft}$ fixtures:

- In an eight-lamp fixture, remove four lamps and replace existing lamps with T8 lamps, install two electronic ballasts and two reflectors. $160 \mathrm{~W}$ savings per fixture.

End Result: Each fixture will have four T8 lamps, two electronic ballasts, reflectors.

For $2 \times 8 \mathrm{ft}$ fixtures:

- In a two-lamp fixture, replace both lamps with eight-foot T8 lamps and install an electronic ballast. $67 \mathrm{~W}$ savings per fixture.

- In a four-lamp fixture, remove two lamps and replace existing lamps with eight-foot T8 lamps and install an electronic ballast and a reflector. $180 \mathrm{~W}$ savings per fixture.

End Result: Each fixture will have two eight-foot T8 lamps, and an electronic ballast.

- In a two 95W T12 lamp fixture, replace lamps with two 60W T12 lamps and replace magnetic ballast with electronic ballast. $111 \mathrm{~W}$ savings per fixture.

- In a two 75W T12 lamp fixture, replace lamps with two 60W T12 lamps and replace magnetic ballast with electronic ballast. $7 \mathrm{~W}$ savings per fixture.

End Result: Each fixture will have two 60W T12 lamps and an electronic ballast. 


\section{APPENDIX D: Savings/Fixture Matrices}


MATRIX A: FLUORESCENT OfFICE FIXTURE (2'X4', 2'X8')

\begin{tabular}{|c|c|c|c|c|c|c|c|c|c|c|c|}
\hline (SAVINGS/FIXTURE): & $\begin{array}{c}2^{\prime} X 4^{\prime} \\
\text { FIXTURE } \\
\text { Replace } \\
\text { magnetic } \\
\text { ballast with } \\
\text { electronic } \\
\text { ballast } \\
\\
\text { (18W/fixture) }\end{array}$ & $\begin{array}{c}2^{\prime} X 4^{\prime} \\
\text { FIXTURE } \\
\text { Delamp 1 } \\
\text { lamp per 3- } \\
\text { lamp fixture, } \\
\text { one } \\
\text { electronic } \\
\text { ballast } \\
\text { (55Wfixture) }\end{array}$ & $\begin{array}{c}2^{\prime} \times 4^{\prime} \\
\text { FIXTURE } \\
\text { Detamp } 2 \\
\text { lamps per 4- } \\
\text { lamp fixture, } \\
\text { one } \\
\text { electronic } \\
\text { bailast, } \\
\text { reflector } \\
\text { (90v } \sqrt{\text { fixture) }}\end{array}$ & $\begin{array}{c}4^{\prime} X 4^{\prime} \\
\text { FIXTURE } \\
\text { Delamp } 4 \\
\text { lamps per 8- } \\
\text { lamp fixture, } \\
\text { two electronic } \\
\text { ballasts, two } \\
\text { reflectors } \\
\text { (160W/fixture) }\end{array}$ & $\begin{array}{c}2^{\prime} \times 8^{\prime} \\
\text { FIXTURE } \\
\text { Replace } \\
\text { magnetic } \\
\text { ballast with } \\
\text { electronic } \\
\text { ballast } \\
\text { (30Wfixture) }\end{array}$ & $\begin{array}{c}2^{\prime} \mathbf{X B}^{\prime} \\
\text { FIXTURE } \\
\text { Delamp } 2 \text { lamps } \\
\text { per } 4 \text {-lamp } \\
\text { fixture, one } \\
\text { electronic } \\
\text { ballast, reflector } \\
\\
\text { (175W/fixture) }\end{array}$ & $\begin{array}{c}\text { Total } \\
\text { capacity } \\
\text { savings } \\
(\mathrm{kW}\end{array}$ & $\begin{array}{c}\text { Operating } \\
\text { hours } \\
\text { (hrs/yr) }\end{array}$ & $\begin{array}{l}\text { Total } \\
\text { energy } \\
\text { savings } \\
\text { (kWh) }\end{array}$ & $\begin{array}{l}\text { Number of } \\
\text { fixtures }\end{array}$ & $\begin{array}{c}\text { Cost } \\
\text { (with E\&I) }\end{array}$ \\
\hline $\begin{array}{l}\text { SAVINGS AT } \\
\text { LOCATION } \\
\text { City Hall } \\
\text { City Hall } \\
\text { City Hall Annex } \\
\text { Maybury Yard } \\
\text { Las Plumas } \\
\text { Main Yard } \\
\text { Pal Building } \\
\text { Leninger Ctr } \\
\text { Leninger Ctr } \\
\text { Gardner Ctr } \\
\text { Gardner Ctr } \\
\text { Starbird Ctr } \\
\text { Berryessa Ctr } \\
\text { Berryessa Libr. } \\
\text { Hank Lopez Ctr } \\
\text { Hank Lopez Ctr } \\
\text { Hank Lopez Ctr } \\
\text { Millbrook Comm Ctr. } \\
\text { Kirk Comm Ctr. } \\
\text { Southside Comm Ctr. } \\
\text { Camden Lifetime Ctr. } \\
\text { Almaden Comm Ctr. } \\
\text { Almaden Comm Ctr. } \\
\text { Almaden Library } \\
\text { Empire Library } \\
\text { Empire Library } \\
\text { Old Convention Ctr. } \\
\text { Fire Stations \& Shop } \\
\end{array}$ & 21.82 & $\begin{array}{l}0.94 \\
2.97\end{array}$ & $\begin{array}{c}7.56 \\
\\
2.79 \\
6.48 \\
10.44 \\
8.10 \\
3.87 \\
\\
3.06 \\
1.44 \\
2.85 \\
4.68\end{array}$ & $\begin{array}{l}1.76 \\
1.60 \\
2.56 \\
0.96\end{array}$ & 14.28 & 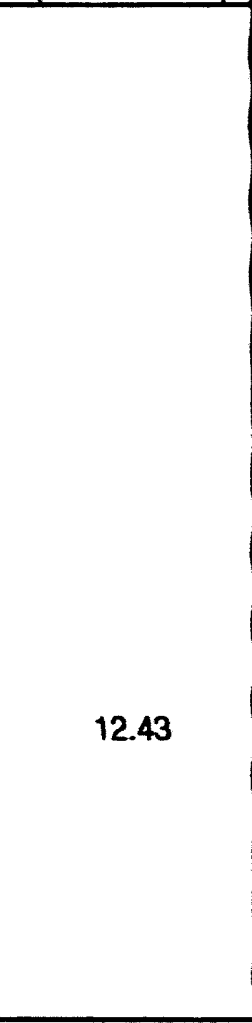 & $\begin{array}{c}14.28 \\
7.56 \\
21.82 \\
2.79 \\
6.48 \\
10.44 \\
8.10 \\
3.87 \\
1.76 \\
3.06 \\
1.60 \\
1.44 \\
2.88 \\
2.56 \\
4.68 \\
0.96 \\
0.94 \\
2.97 \\
0.63 \\
12.43 \\
4.32 \\
0.18 \\
5.44 \\
2.52 \\
0.54 \\
0.33 \\
2.16 \\
10.71 \\
\end{array}$ & $\begin{array}{l}2800 \\
2800 \\
2800 \\
2500 \\
2500 \\
2500 \\
2500 \\
2700 \\
2200 \\
1250 \\
1250 \\
2000 \\
2000 \\
2700 \\
3000 \\
3300 \\
1000 \\
2000 \\
2000 \\
1500 \\
1500 \\
2000 \\
2000 \\
2700 \\
2700 \\
2700 \\
2600 \\
3650 \\
\end{array}$ & $\begin{array}{c}39984 \\
21168 \\
61085 \\
6975 \\
16200 \\
26100 \\
20250 \\
10449 \\
3872 \\
3825 \\
2000 \\
2880 \\
5760 \\
6912 \\
14040 \\
3168 \\
935 \\
5940 \\
1260 \\
18637.5 \\
6480 \\
360 \\
10880 \\
6804 \\
1458 \\
891 \\
5616 \\
39092 \\
\end{array}$ & $\begin{array}{c}476 \\
84 \\
1212 \\
31 \\
72 \\
116 \\
90 \\
43 \\
11 \\
34 \\
10 \\
16 \\
32 \\
16 \\
52 \\
8 \\
17 \\
54 \\
7 \\
71 \\
48 \\
2 \\
34 \\
28 \\
6 \\
6 \\
24 \\
119 \\
\end{array}$ & $\begin{array}{r}\$ 21,420 \\
\$ 7,560 \\
\$ 36,360 \\
\$ 2,790 \\
\$ 6,480 \\
\$ 10,440 \\
\$ 8,100 \\
\$ 3,870 \\
\$ 1,760 \\
\$ 3,060 \\
\$ 1,600 \\
\$ 1,440 \\
\$ 2,880 \\
\$ 2,560 \\
\$ 4,680 \\
\$ 1,280 \\
\$ 595 \\
\$ 1,890 \\
\$ 630 \\
\$ 11,360 \\
\$ 4,320 \\
\$ 180 \\
\$ 5,440 \\
\$ 2,520 \\
\$ 540 \\
\$ 210 \\
\$ 2,160 \\
\$ 10,710\end{array}$ \\
\hline TOTALS & 21.82 & 4.24 & 72.36 & 12.32 & 14.28 & 1243 & 137.44 & & 343,021 & & $\$ 156,835$ \\
\hline Measure cost/fixture: & $\$ 30.00$ & $\$ 35.00$ & $\$ 90.00$ & $\$ 160.00$ & $\$ 45.00$ & $\$ 160.00$ & & & & & \\
\hline
\end{tabular}


MATRIX B: AIRPORT-FLUORESCENT OFFICE-TYPE FIXTURES (2'X4', 2'X8')

\begin{tabular}{|c|c|c|c|c|c|c|c|c|c|c|c|}
\hline & $\begin{array}{l}2 \times 4^{\circ} \\
\text { FIXTURE }\end{array}$ & $\begin{array}{l}2^{\prime} \times 4^{\prime} \\
\text { FIXTURE }\end{array}$ & $\begin{array}{l}2^{\prime} \times 4^{\prime} \\
\text { FIXTURE }\end{array}$ & $\begin{array}{l}\text { 2'X8' } \\
\text { FIXTURE }\end{array}$ & $\begin{array}{l}2^{\prime} \times 8^{\prime} \\
\text { FIXTURE }\end{array}$ & & & & & & \\
\hline (SAVINGS/FIXTURE): & $\begin{array}{c}\text { Replace 2- } \\
\text { T12's, 1-Mag. } \\
\text { ballast with } \\
\text { 2-T8's, } \\
\text { 1-Elec. } \\
\text { ballast } \\
\text { (20W/fixture) }\end{array}$ & $\begin{array}{c}\text { Replace 3- } \\
\text { T12's, 2- } \\
\text { Mag. ballast } \\
\text { with 3-T8's, } \\
\text { 1-Elec. } \\
\text { ballast } \\
\text { (36Wfixture) }\end{array}$ & $\begin{array}{c}\text { Replace 4- } \\
\text { T12's, 2-Mag. } \\
\text { ballast with 4- } \\
\text { T8's, 1-Elec. } \\
\text { ballast }\end{array}$ & $\begin{array}{l}\text { Replace 2-95W } \\
\text { T12's, 1-Mag. } \\
\text { ballast with } \\
\text { 2-60W T12's, } \\
\text { 1-Elec. ballast } \\
\\
\text { (111W/fixture) }\end{array}$ & $\begin{array}{c}\text { Replace 2- } \\
75 \text { W T12's, 1- } \\
\text { Mag. ballast } \\
\text { with } \\
\text { 2- } 60 \text { W T12's, } \\
\text { 1-Elec. } \\
\text { ballast } \\
\text { (67Wfixture) }\end{array}$ & $\begin{array}{c}\text { Total } \\
\text { capacity } \\
\text { savings } \\
\text { (kW) }\end{array}$ & $\begin{array}{l}\text { Operating } \\
\text { hours } \\
\text { (hrs/yr) }\end{array}$ & $\begin{array}{l}\text { Total } \\
\text { onergy } \\
\text { savings } \\
\text { (kWh) }\end{array}$ & $\begin{array}{l}\text { Number of } \\
\text { fixtures }\end{array}$ & $\begin{array}{c}\text { Cost } \\
\text { (matrl \& labor) }\end{array}$ & \# of lamps \\
\hline $\begin{array}{l}\text { SAVINGS BY } \\
\text { LOCATION } \\
1395 \text { Airport Blvd. }\end{array}$ & 0.240 & & & & & 0.24 & 3380 & 811.2 & 12 & $\$ 720$ & 24 \\
\hline $\begin{array}{l}1395 \text { Airport Blvd. } \\
1395 \text { Airport Blvd. } \\
1395 \text { Airport Blvd. } \\
1395 \text { Airport Blvd. } \\
1311 \text { Airport Blvd. }\end{array}$ & 0.680 & 3.096 & 0.950 & 0.444 & 0.402 & $\begin{array}{l}3.10 \\
0.95 \\
0.44 \\
0.40 \\
0.68\end{array}$ & $\begin{array}{l}3380 \\
3380 \\
3380 \\
3380 \\
3120\end{array}$ & $\begin{array}{c}10464 \\
3211 \\
1501 \\
1359 \\
2121.6\end{array}$ & $\begin{array}{c}86 \\
19 \\
4 \\
6 \\
34\end{array}$ & $\begin{array}{c}\$ 5,590 \\
\$ 1,330 \\
\$ 280 \\
\$ 420 \\
\$ 2,040\end{array}$ & $\begin{array}{l}258 \\
76 \\
68\end{array}$ \\
\hline $\begin{array}{l}1311 \text { Airport Blvd. } \\
\text { Airplane Shelters } \\
1401 \text { Airport Blvd. } \\
1101 \text { Airport Blvd. } \\
\text { Warehouse Bldg. }\end{array}$ & $\begin{array}{l}0.800 \\
0.500\end{array}$ & & $\begin{array}{l}1.400 \\
1.350\end{array}$ & 2.442 & & $\begin{array}{l}1.40 \\
0.80 \\
1.35 \\
0.50 \\
2.44\end{array}$ & $\begin{array}{l}3120 \\
2000 \\
3400 \\
3400 \\
4420\end{array}$ & $\begin{array}{c}4368 \\
1600 \\
4590 \\
1700 \\
10794\end{array}$ & $\begin{array}{l}28 \\
40 \\
27 \\
25 \\
22\end{array}$ & $\begin{array}{l}\$ 1,960 \\
\$ 2,400 \\
\$ 1,890 \\
\$ 1,500 \\
\$ 1,540\end{array}$ & $\begin{array}{c}112 \\
80 \\
108 \\
50\end{array}$ \\
\hline TOTAL & 2.220 & 3.096 & 3.700 & 2.886 & 0.402 & 12.304 & & 42,519 & & $\$ 19,670$ & \\
\hline $\begin{array}{l}\text { 24-HOUR, 7-DAY } \\
\text { OPERATION } \\
\text { Ap Main Terminal } \\
\text { Ap Main Terminal } \\
\text { 1101 Airport Blvd. } \\
1803 \text { Airport Blvd. }\end{array}$ & $\begin{array}{l}13.220 \\
0.400 \\
1.340\end{array}$ & & 50.650 & & & $\begin{array}{c}13.220 \\
50.650 \\
0.40 \\
1.34\end{array}$ & $\begin{array}{l}8700 \\
8700 \\
8700 \\
8700\end{array}$ & $\begin{array}{c}115014 \\
440655 \\
3480 \\
11658\end{array}$ & $\begin{array}{c}661 \\
1013 \\
20 \\
67\end{array}$ & $\begin{array}{c}\$ 39,660 \\
\$ 70,910 \\
\$ 1,200 \\
\$ 4,020\end{array}$ & $\begin{array}{l}1322 \\
4052\end{array}$ \\
\hline 1803 Airport Blvd. & & & & & 0.603 & 0.60 & 8700 & 5246.1 & 9 & $\$ 630$ & \\
\hline TOTAL & 14.960 & 0.000 & 50.650 & 0.000 & 0.603 & 66.213 & & 576,053 & & $\$ 116,420$ & 6150 \\
\hline $\begin{array}{l}\text { Measure cost/fixture } \\
\text { (materials \& labor): }\end{array}$ & $\$ 60.00$ & $\$ 65.00$ & $\$ 70.00$ & $\$ 70.00$ & $\$ 70.00$ & 78.52 & & 618,573 & & $\$ 136,090$ & \\
\hline
\end{tabular}




\title{
REPORT AND INFORMATION SOURCES
}

Additional copies of this report, "Negotiating A Demand Side Bid: City of San Jose Case Study," are available from:

\author{
Publications and Distribution \\ Public Technology, Incorporated \\ 1301 Pennsylvania Avenue, N.W. \\ Washington, D.C. 20004
}

For information on the structure, operation, and results of this study, contact:

\author{
Rita Norton \\ Unit Manager \\ Conservation Services Division \\ City of San Jose \\ 777 North First Street \\ Suite 450 \\ San Jose, CA 94112 \\ (408)277-5533
}




\section{Publications Price List-UCETF Reports}

\section{TITLE}

PRICE

ITEM \#

Hydraulic Waste Energy Recovery: A Technical Report

15.00

A Regulatory Framework for Alternative Fuels and Transportation Management Services

90-318

Alternative Vehicle Fuels: A Demonstration Project

90-316

Energy Efficiency in Public Housing

15.00

90-314

Analysis of Programmatic Fleet Conversion to Ethanol Blends

89-330

An Alternative Fuels Evaluation System for Fleet Vehicles

15.00

$89-325$

Dual Fuel Conversion Demonstration and Technology Transfer Project

10.00

$89-323$

Summary of Low and Moderate Income Residential Energy Conservation Programs

$89-321$

A Case Study in the Pursuit of Urban Energy Efficiency

15.00

89-315

Communicating with the Public About Environmental Health Risks: A Case Study

13.00

$89-314$

Evaluation and Comparison of Selected Household Hazardous Waste Collection Facilities

$89-313$

15.00

89-311 Yard Waste Recycling Study: A Pilot Study

15.00

89-310 Sludge Storage Lagoon Biogas Recovery and Use, Volume 1

89-307 Proceeding: 1989 Electric Utility Franchise Conference

$89-306$

Reducing Electricity Demand Through Energy-Related Efficient Construction

15.00

89-304 Modernization of Lighting in Municipal Auditoriums

89-303 Wastewater Treatment Process Energy Optimization

14.00

89-301 Implementation of Alternative Technologies through the Assessment of Energy Markets

15.00

88-322 Marketing Energy Efficiency Programs to Commercial and Industrial Firms: Lighting Incentives and

88-321 Urban Energy Management Today: Ten Year Compendium of UCETF Programs

10.00

88-319 Integrating Energy Efficiency Into Municipal Purchasing Decisions: Computerizing Procurement 15.00

88-318 Household Hazardous Waste: Implementation of a Permanent Collection Facility

88-317 Hazardous Waste as an Energy Manager's Issue

88-316

Household Hazardous Waste Management Planning

$88-312$

Summary of Small Business Energy Conservation Programs

88-306 HVAC Equipment Replacement for Best Size and Efficiency, Transfer Report

Energy Master Planning: Innovative Design and Energy Analysis Services for New Commercial

88-303 Energy Efficient Building Design: Guidelines for Local Government 
Publications Price List--UCETF Reports TITLE

PRICE

ITEM \#

87-313 Computer Assisted Control for Municipal Water Systems, Phase II

87-312 Economic Development Through Energy Technology Tranfer

87-311 Electric Utility Franchise Guide

87-310 Hidden Link: The Energy and Economic Development, Phase II

18.00

87-307 Municipal Underground Storage Tanks: An Energy Manager's Guide

20.00

87-306 Intergrating Energy Efficiency into Mun. Purchasing Decisions

40.00

87-305 Energy Enhancement in New Residential Construction

20.00

$87-302$

Thermal Energy Storage: Application Guide for Local Governments

20.00

87-301 HVAC Equipment Replacement for Best Size \& Efficiency

20.00

86-315 Balancing Single Pipe Steam Heating Sytems

20.00

86-314 Inhibition of Respiration in Activated Sludge by High Carbon Dioxide Concentration

7.50

86-313 Water Supply System Energy Conservation Through Computer Control

18.00

86-312 Energy Cost Reduction Through Wastewater Flow Equalization 20.00

86-311 High Efficiency Gas Furnace Modification in Low Income Housing 15.00

86-310 Hidden Link: Energy and Economic Development, Phase I 15.00

86-307 Disposal Techniques with Energy Recovery for Scrapped Vehicle Tires 20.00

86-306 District Heating Marketing: Analysis of a Twelve City Survey 20.00

86-305 Technology Transfer for Residential Energy Programs in New Construction and Existing Housing 15.00

86-304 Technology Transfer for Residential Energy Efficiency 15.00

86-302 Neighborhood Energy Efficiency \& Reinvestment 15.00

86-301 On-Site Municipal Fuel Cell Power Plan: Feasibility and Application Guide 15.00

85-326 Resource Recovery for Urban Yard Waste 18.00

85-323 Energy Monitoring and Controlling in Municipal Facilities 10.00

85-320 Transportation Management for Business Relocation 15.00

85-319 District Heating in Denmark 10.00

85-318 Computer-Assisted Control for Municipal Water Systems, Phase I 18.00

85-317 Financing Energy Efficient Housing as a Community Economic Development Tool 15.00

85-316 Modular District Heating Planning as a Development Tool 15.00

85-314 Alternative Techniques for Dev. of Energy Efficient Residences 15.00

85-312 Shared Savings and Low Income Homeowners 18.00

85-311 Measures and Investment Options for Community Energy Conservation 18.00

85-310 Planning for Energy Efficiency in New Commercial Buildings 15.00

85-308 Residential Space Heating with Wood 15.00

85-307 Thermal Storage Strategies for Energy Cost Reduction 18.00

84-325 Shared Savings in the Residential Market

84-324 Methanol Use in Vehicle Fleet Operations: Barriers 20.00

84-322 Energy Management and Technology for Urban Governments 15.00

84-321 Hydrate Process for Waste Water Treatment Plant Sludge Dewatering 15.00 


\section{Publications Price List-UCETF Reports}

TITLE

PRICE

ITEM \#

84-320

Development of Computerized Inventory and Maintenance System for Municipal Street Lights

84-315 Facilities Energy Monitoring System

15.00

84-314

Application of Mini-Van Technology to Vanpool Services

15.00

84-312 Implementation Methods for an Integrated Energy System

Feasibility of Water-Based District Heating and Cooling

10.00

84-311

Budgetary Incentives for Municipal Energy Management

$84-310$

Central Energy Systems Applications to Economic Development

22.00

$84-309$

On-Site Cogeneration for Office Buildings

20.00

84-308

Analysis of Municipal Bus Operations for the Advancement of Fuel Cell Technology

84-306

84-305 Computer Based Maintenance

15.00

84-304 Innovative Finance Plans for Privately Owned Waste/Vol. 2

84-303 Innovative Finance Plans for Privately Owned Waste/ Vol. 1

15.00

$84-301$

Coordinating Preventive Maintenance with Energy Management

15.00

15.00

83-319 The Rehabilitation and Retrofit of Older Houses to Superinsulated Standards

15.00

83-318 Developing Sources and Techniques for Alternative Financing of Energy Conservation

20.00

83-316 Hydrate Process for Dewatering Sewage Sludge

10.00

$83-315$

Financial Planning for District Heating: Brooklyn Navy Yard

15.00

83-314 Memphis Area Rideshare On-Line Information System

18.00

$83-313$

Renovation Opportunities for Steam District Heating Systems

18.00

83-312 Initial Assessment of District Heating and Cooling

20.00

83-311 Energy Conservation Through Computerized Automation

18.00

83-309 Development of an Energy Park: Issues and Implementation Options

15.00

83-308 Alternative Uses for Digester Methane Gas

25.00

83-307 Innovative Financing and Incentive Package to Reduce Energy

15.00

83-305 Multi-Jurisdictional Planning for District Heating and Cooling

10.00

83-303 Improving Energy Management and Accountability in Municipal Operations

15.00

82-320 Utilization of Felled City Trees as Supplemental Boiler Fuel

7.50

82-319 Methanol Use in Vehicle Fleet Operations: Comparisons

15.00

82-317 Microcompter Tools for Trans. and Residential Energy Conservation

20.00

82-316 Reduction of Impediments to Alternative Energy Use

20.00

82-315 Reducing Regulatory and Financial Impediments to Energy Conservation

20.00

82-314 Integrating Energy Management with Economic Development

20.00

$82-313$

Energy Conservation and Economic Development

10.00

$82-310$

Municipal Technologies

20.00

82-307

Strategies to Improve Community Energy Use Practices

10.00

82-306 Energy Conservation In Water Treatment

82-305 Development of an Energy Action Plan: Participating Approach 
Publications Price List-UCETF Reports

TITLE

PRICE

ITEM \#

Public Housing Energy Efficiency Through Private Financing

10.00

\begin{tabular}{|c|c|c|}
\hline $82-300$ & Developing an Energy Management Tracking System & \\
\hline $81-328$ & Matching End Use Energy Needs to Source Possibilities & 20.00 \\
\hline $81-327$ & Development of a Hydrogen-Fueled Mass Transit Vehicle s & 15.00 \\
\hline $81-326$ & Operational and Maintenance Guidelines for Reducing Energy Consumption & \\
\hline $81-324$ & Energy Management for Small Business & 10.00 \\
\hline $81-320$ & Energy Data Gathering, Analysis, and Review System & 20.00 \\
\hline $81-318$ & Fuel Management and Planning System for Local Government & 25.00 \\
\hline $81-316$ & Production of Ethanol from Cellulosic Fraction & \\
\hline $81-313$ & Metro-Dade County Comprehensive Energy Emergency Plan & \\
\hline $81-311$ & Developing Energy Emergency Prepardness & 15.00 \\
\hline $81 \cdot 310$ & Simplified Methodology for Community Energy Management & 20.00 \\
\hline $81-309$ & Energy Management: The Public Sector & 15.00 \\
\hline $81 \cdot 307$ & Municipal Technical Assistance-Energy Monitoring & 6.00 \\
\hline $81-306$ & New Technology Demonstration & 10.00 \\
\hline $81-305$ & Technology Transfer: Unit Report from the Energy Task Force & 15.00 \\
\hline $81-304$ & Development of Local Energy Management Preparedness & 10.00 \\
\hline $81-303$ & Municipal Energy Management & 10.00 \\
\hline $80-314$ & Methodology for Energy Impact Analysis of Urban Development Projects & 15.00 \\
\hline $80-313$ & Evaluation of Landfill Gas as an Energy Source & 15.00 \\
\hline $80-309$ & Decision Process for the Retrofit of Municipal Buildings & 20.00 \\
\hline $80-308$ & Primary Urban Energy Management Planning Methodology & 7.50 \\
\hline $80-306$ & Local Government Use of Thermography for Energy & 15.00 \\
\hline $79-300$ & Planning for and Purchasing Computer Technology & 6.50 \\
\hline
\end{tabular}



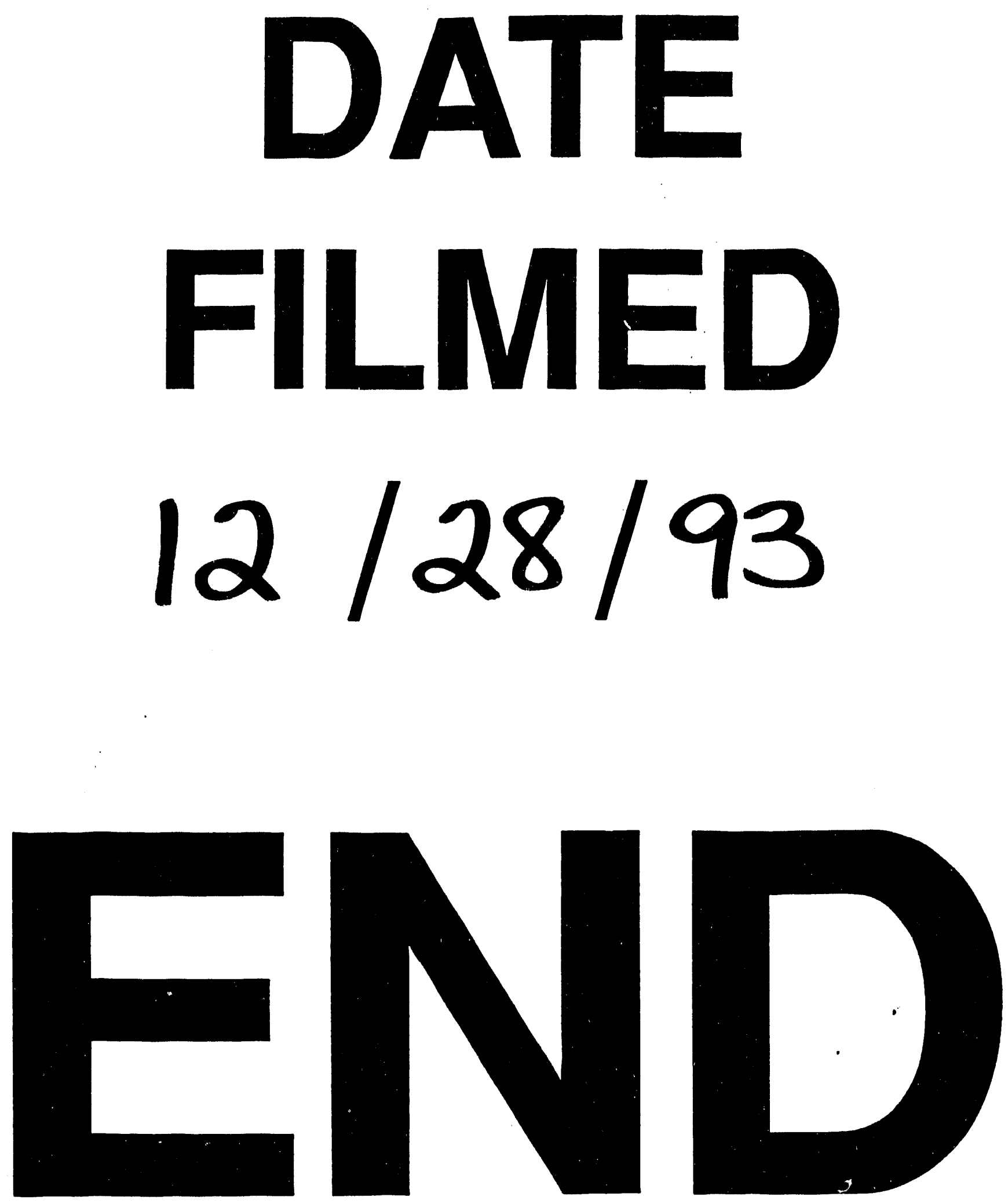
